\title{
German bank lending during emerging market crises: A bank level analysis
}

\section{Frank Heid}

(Deutsche Bundesbank)

Thorsten Nestmann

(Universität Mainz)

Beatrice Weder di Mauro

(Universität Mainz)

Natalja von Westernhagen

(Deutsche Bundesbank)

Discussion Paper

Series 2: Banking and Financial Supervision No $04 / 2004$ 
Editorial Board:

Heinz Herrmann

Thilo Liebig

Karl-Heinz Tödter

Deutsche Bundesbank, Wilhelm-Epstein-Strasse 14, 60431 Frankfurt am Main, Postfach 1006 02, 60006 Frankfurt am Main

Tel +49 69 9566-1

Telex within Germany 41227, telex from abroad 414431, fax +49695601071

Please address all orders in writing to: Deutsche Bundesbank,

Press and Public Relations Division, at the above address or via fax No +49 69 9566-3077

Reproduction permitted only if source is stated.

ISBN 3-86558-021-1 


\begin{abstract}
This paper studies German bank lending during the Asian and Russian crises, using a bank level data set, which has been compiled from credit data at the Deutsche Bundesbank. Our aim is to gain more insight into the pattern of German bank lending during financial crises in emerging markets. We find that German banks reacted to the Asian crisis mainly by reallocating their portfolios among emerging markets. This behaviour is consistent with active portfolio management and does not necessarily indicate a spontaneous reaction to the Asian crisis. By contrast, the banks' behaviour during the Russian crisis is characterised by a general withdrawal from emerging markets. The use of micro data allows us to analyse and to model bank heterogeneity with panel estimation techniques. We find that the lending of large commercial banks was less stable than the lending of public sector banks during the Asian crisis. Differences were not as pronounced during the Russian crisis.
\end{abstract}

Keywords: banking, currency crises, emerging markets crises, contagion, financial stability, bank lending

JEL classification: F30; F32; F34 


\section{Non technical summary}

In this paper, we analyse German bank lending during the Asian and Russian crises. Earlier studies have shown that banks with large credit exposures to the original crisis country significantly reduced their exposures to countries which were not yet afflicted by the crisis. The probability of contagion therefore increases for those countries which have common lenders with the crisis country. The transmission mechanism of a crisis can thus be explained by the need of banks to rebalance the overall volume of loans among emerging market economies, owing to losses suffered or an increased credit risk in the countries involved into a crisis. This reflects a normal adjustment mechanism, which is not necessarily associated with a general re-assessment of emerging markets risk.

The "wake-up call" is a different matter. This is characterised by the fact that banks generally correct their risk perception of emerging market economies shortly after the start of a crisis. This is of crucial importance for both the lending banks and the emerging market economies because a country's creditworthiness can change relatively quickly without this being initially evident from the available data.

In this connection, it is also important to establish whether, apart from the above-mentioned effects, the two crises also led to changes in the regional composition of credit portfolios. Whereas the "common lender" effect and the "wake-up call" cause withdrawal of credit business from all emerging markets, this regional effect leads to a greater differentiation of bank lending to emerging markets. It is important to note, that the reallocation can only be partly attributed to the fundamental factors considered in our analysis.

Bank behaviour during the two crises under review differed considerably with regard to the significance of the three factors. Whereas in the Asian crisis portfolio considerations tend to be the decisive factor, the Russian crisis is characterized by a general rise in the risk aversion. Furthermore, the reactions of the categories of banks considered, namely large commercial and public sector banks, differed in their intensity, at least during the Asian crisis. For example, during the Asian crisis, the large commercial banks reacted more aggressively than public sector banks. The differences were less pronounced in the Russian crisis, however. 


\section{Nichttechnische Zusammenfassung}

In diesem Papier untersuchen wir das Kreditvergabeverhalten deutscher Banken in der Asienund Russlandkrise. Frühere Studien haben unter anderem gezeigt, dass Banken, die hohe Kreditforderungen im ursprünglichen Krisenland hielten, ihre Kreditengagements auch in anderen, sich noch nicht in der Krise befindlichen Ländern deutlich reduzierten. Die Krisenanfälligkeit stieg daher für jene Länder, die Kreditgeber mit dem Krisenland gemein hatten ("Common lender effect"). Die Übertragung einer Krise erklärt sich demnach aus der Tatsache, dass Banken aufgrund erlittener Verluste bzw. aufgrund eines gestiegenen Kreditrisikos im Krisenland das Volumen ihrer Kredite an andere Schwellenländer vermindern. Im Grunde handelt es sich hierbei um eine normale Portfolioanpassung, die nicht notwendigerweise mit einer allgemeinen Neubewertung des Kreditrisikos hinsichtlich der Schwellenländer einhergeht.

Anders verhält es sich, wenn Banken kurz nach dem Beginn einer Krise ihre Risikowahrnehmung in Bezug auf Schwellenländer generell korrigieren ("Wake up call"). Diese Neubewertung der Schwellenländer führt per se zu Kreditabflüssen aus allen Schwellenländern. Für Banken wie auch für die betroffenen Länder als Kreditnehmer ist dies von entscheidender Bedeutung, da es zeigt, dass sich die Kreditwürdigkeit eines Landes verhältnismäßig rasch ändern kann, ohne dass diese Entwicklung aus der Datenlage ex ante zu prognostizieren wäre.

Wir analysieren in diesem Zusammenhang auch, inwieweit die Banken während der beiden Krisen die regionale Zusammensetzung ihrer Kreditportfolien änderten. Während der "Common lender effect" und der "Wake up call" eine unterschiedslose Rücknahme des Kreditgeschäfts bewirken, führt dieser Regionaleffekt zu einer stärkeren Ausdifferenzierung der Kreditvergabe. Die Umschichtungen können dabei nur zum Teil durch die von uns berücksichtigten Fundamentalfaktoren erklärt werden.

Unsere Untersuchungen zeigen, dass sich die deutschen Banken in den beiden Krisen recht unterschiedlich verhielten. Während in der Asienkrise tendenziell Portfoliogesichtspunkte den Ausschlag gaben, so ist die Russlandkrise durch einen starken Anstieg der Riskioaversion gekennzeichnet. Dabei wichen die Reaktionen der in unserer Studie betrachteten Bankengruppen - die der Großbanken und die der Landesbanken - hinsichtlich ihrer Intensität voneinander ab. So haben die Großbanken während der Asienkrise aggressiver reagiert als die Landesbanken; allerdings sind die Unterschiede in der Russlandkrise weniger stark ausgeprägt. 


\section{Contents}

1 Introduction 1

2 Choice of determinants of international bank lending and propagation of crises 2

3 Background information on the German banking system 4

4 Data sources $\quad 5$

5 Stylised facts on German bank lending during crises 6

$\begin{array}{ll}6 \text { Empirical model } & 8\end{array}$

7 Results 10

8 Summary and conclusion $\quad 15$

$\begin{array}{ll}\text { Appendix } & 16\end{array}$

$\begin{array}{ll}\text { References } & 27\end{array}$ 


\section{German bank lending during emerging market crises: A bank level analysis *\#}

\section{Introduction}

International banks have been blamed for contributing significantly to the transmission of shocks among emerging markets. There are good theoretical reasons to believe that banks might be one of the prime sources of shock transmission. ${ }^{1}$ The empirical literature on financial contagion is now very extensive, and there are several studies that document a special role for bank lending. In particular, it has been shown that countries which share the same bank lender as a crisis country are more likely to suffer from shock transmission than others. ${ }^{2}$ However, most of the existing literature has used aggregated data on financial flows to assess the role of bank lending. This macro approach was partly dictated by the data available. While the Bank for International Settlements (BIS) offers a ready source of aggregated data, publicly available individual bank data are generally scarce.

The Bundesbank collects data on all credits (foreign and domestic) that exceed $€ 1.5$ million. We aggregate and consolidate the credit level data for each individual corporate banking group in order to exclude inter-office positions. Analysing individual bank flows allows us to test conjectures that have been put forward in the existing literature. In contrast to earlier studies, this paper focuses mainly on bank behaviour rather than on its consequences for emerging markets. In particular, we analyse whether changes in the pattern of German bank lending during the Asian and Russian crises were driven mainly by portfolio management rules or, alternatively, by a sudden generalised increase in risk aversion towards emerging economies. Thus, we are mainly interested in how German banks reacted to these crises and remain cautious when interpreting the consequences of German bank lending to emerging markets as German banks, although one of the major creditors, account for only $20 \%$ of all bank lending to emerging markets (see Figure 1).

First, assuming that the banks are significantly exposed to a crisis country, we want to analyse to what extent a crisis in one country influences their lending decisions with respect to other countries. Second, we test whether or not a crisis causes banks to change their overall risk perception indiscriminately with respect to emerging markets. Third, we are interested in the regional composition of the banks' loan portfolios and whether they were altered in the aftermath of the initial crisis. Fourth, we test the importance of some early warning indicators

\footnotetext{
* This paper is part of a project between the Bundesbank and the Chair for International Macroeconomics at the University of Mainz. The authors would like to thank Thilo Liebig, Daniel Porath, Dieter Urban, Michael Wedow, Jörg Breitung and participants of seminars held at the Bundesbank, the Young Economist Conference in Warsaw (2004), the Conference on Emerging Markets and Global Risk Management in London (2004) and the IMF course "Policies for Monetary and Financial Stability" in Washington D.C. (2004) for support and discussions. Heinz-Michael Ritter and Bjoern Wehlert have provided many helpful comments on the database for German foreign claims. All errors and inaccuracies are solely our own responsibility.

\# Corresponding authors’ E-mail: Nestmann@uni-mainz.de; Natalja.von-Westernhagen@bundesbank.de

${ }^{1}$ For instance, Schinasi and Smith (2000) show that portfolio management rules can lead to "contagious" behaviour.

${ }^{2}$ See, for example, Caramazza et al (2000), Kaminsky and Reinhard (2000), Hernández and Valdés (2001), and Van Rijckeghem and Weder (2001, 2003).
} 
for financial crises and whether they had any impact on German bank lending. Apart from analysing determinants of bank lending during crises, we also take a closer look at differences among banking groups, in particular at the behaviour of large commercial banks versus public sector banks. This is an important issue since public sector banks enjoy a government guarantee, ${ }^{3}$ which may influence their lending decisions. Furthermore, we use risk-adjusted claims net of credit guarantees, which should provide a good proxy of banks' actual exposure to emerging markets. This is important since van Rijckeghem and Weder (2003), by using BIS data, show that German lending differed from that of other banking centres during the Russian crisis and attributed this to the special role of government guarantees. ${ }^{4}$

German banks did, in fact, behave very differently during the Asian and Russian crises. While banks which were significantly exposed to South Korea reduced their claims on other emerging markets, banks' exposure to Russia cannot explain subsequent credit flows to other countries. During the Asian crisis, banks reallocated claims from Asia to the Western Hemisphere and Emerging Europe. Following the Russian default, however, banks departed from almost all emerging market regions except Emerging Europe. Furthermore, countries' macroeconomic conditions and financial linkages played a role during the Asian crisis but not so during the Russian crisis, where we observe a general withdrawal from emerging markets. With respect to differences among banking groups, we find that, during the Asian crisis, large commercial banks reacted more strongly than public sector banks. By contrast, we find no significant differences between banking groups during the Russian crisis.

The paper is structured as follows. Section 2 describes our choice of bank lending determinants during crises. In section 3, we briefly explain the structure of the German banking system. Section 4 describes the data sources, and section 5 presents stylised facts about banks' foreign exposures and banks' reactions to the crises considered. The empirical methodology applied in this paper is outlined in section 6 , with results presented in section 7 . Section 8 concludes.

\section{Choice of determinants of international bank lending and propagation of crises}

The relevant literature for this paper can be divided into two broad categories: that on international financial contagion and the one on the determinants of international bank lending. ${ }^{5}$ According to the existing literature, the most important factors determining bank lending to emerging markets in crisis periods seem to be financial and trade linkages with the crisis country as well as specific macroeconomic fundamentals. However, we especially opt for financial linkages since they are identified in the literature to be the most prominent in the propagation of recent crises in emerging markets.

\footnotetext{
${ }^{3}$ A detailed overview of the role of the Land banks within the German financial system is given in Sinn (1999).

${ }^{4}$ Note that we use a different data source. The aggregated BIS data therefore cannot be compared directly with our data set. See Nestmann et al (2003) for further details on the differences between the two data sources.

${ }^{5}$ For a review of the literature on contagion, see, for example, IMF (1999) or Christiansen (2000). Several papers on contagion have been compiled in a book on international financial contagion by Claessens and Forbes (2001). For an overview of literature on determinants of international bank lending to emerging markets see, for example, Jeanneau and Micu (2002).
} 
On financial linkages, our study draws mainly on previous research by van Rijckeghem and Weder (2003). Using aggregated data from the Bank for International Settlements (BIS) on major banking centres, they investigated the presence of a "common lender" effect in the Mexican, Asian and Russian crises for a panel of 30 emerging markets. For the Mexican and Asian crises, they find that emerging countries were more likely to suffer from financial contagion if they were borrowing from the same banking centre as the initial crisis country. In the literature this has been called contagion due to a "common lender" effect. Banks as "common lenders" are not only able to deepen the crisis in the original crisis country but also to propagate crises in other emerging markets. Banks experiencing substantial initial losses in a crisis country need to recapitalise, provision and meet margin calls. Following the need to reduce their overall risk, the banks tend to rebalance asset portfolios by calling up loans and drying up credit lines. The withdrawals of "common lenders" can lead to remarkable capital outflows from emerging markets where banks were previously significantly exposed and trigger a crisis in the countries involved. The need for the withdrawal in the face of losses is often induced by the Value-at-Risk models or similar models. The importance of banks as common lenders in the Asian and Russian crises has also been discussed by Kaminsky, Reinhart and Végh (2003), Kaminsky and Reinhart (2000, 2001), Hernandes and Valdes (2001) and Caramazza et al (2000). Schinasi and Smith (2000) show how investors reduce their risky asset positions as a reaction to an adverse shock to a single asset's return distribution to achieve optimal portfolio rebalancing according to Value-at-Risk rules.

For the Russian crisis, van Rijckeghem and Weder (2003) find a more general reversal of bank flows owing to a "wake up call" effect. This transmission channel assumes that banks pull out of emerging markets altogether, once a crisis starts to unfold. This reaction may be caused by a sudden increase in banks' risk aversion with respect to emerging markets which exhibit similarities in fundamentals with the initial crisis country or even with respect to emerging markets in general. ${ }^{6}$ Owing to this effect, the crisis spills over to other emerging markets even if financial linkages due to common lenders are weak. The "wake up call" is therefore quite different from the "common lender" effect although both can lead to substantial capital reversals from emerging markets. In the latter it is rather a rebalancing of the banks' portfolios owing to losses sustained in the crisis whereas in the former the capital outflow is more likely to be due to a general re-assessment of emerging market risk.

Stock market linkages are another channel of financial contagion identified in the literature. Buissière and Fratzscher (2002) show that the probability of a crisis transmission significantly increases if pre-crisis stock market returns are highly correlated. Similarly, Kaminsky and Reinhart (2000) find that contagion spreads first to countries whose stock market returns exhibit a high degree of co-movement with the initial crisis country. According to Kodres and Pritsker (2002), who investigate investors' cross-market hedging, countries which exhibit above-average stock return correlation with the crisis country are more vulnerable to contagion as a result of cross-market hedges.

Trade linkages, which have also been shown to contribute to the transmission of crises, can be of a direct nature, such as bilateral trade between the crisis country and other countries, or of an indirect nature. Indirect trade linkages occur as a result of countries competing with the crisis country in common third markets. While competing with the initial crisis country in common third markets, other emerging markets could lose their competitiveness and

\footnotetext{
${ }^{6}$ See, for example, Eichengreen et al (1996), Goldstein (1998) and Goldstein et al (2000).
} 
devaluate. In fact, Glick and Rose (1999) and Corsetti et al (1998) find empirical evidence that both direct and indirect trade linkages do contribute to the spread of currency crises. Trade linkages between countries also influence bank lending decisions. For example, banks may pull out of those countries which they expect to be vulnerable owing to trade linkages with a crisis country.

Also, weak macroeconomic fundamentals sometimes trigger larger capital outflows if investors interpret these as warning signals. In particular, current account balance over GDP, the budget balance over GDP, the ratio of M2 over reserves as well as real exchange rate appreciation and credit growth to the private sector taken in the pre-crisis period have been used as early warning signals.

\section{Background information on the German banking system}

The German banking system is characterised by a large number of credit institutions, which vary widely in terms of size, customer structure, business model and regional orientation. Banks can be classified as belonging to one of the following banking groups: commercial banks, savings banks, central institutions of the savings banks (Land banks), credit cooperatives, regional institutions of credit cooperatives, mortgage banks and other banks.

All private universal banks are classified as commercial banks. They are the most heterogeneous of all the groups. Commercial banks include large commercial banks (Deutsche Bank, Dresdner Bank, Commerzbank, HypoVereinsbank), ${ }^{7}$ regional banks and branches of foreign banks. Besides the legal form of a public limited company (Aktiengesellschaft), another characteristic of large commercial banks is their national and international orientation. As universal banks, they offer all the standard banking services to all the major domestic target groups. Large commercial banks are active abroad to varying extents. Although, as global players, they are represented in all major markets, only in exceptional cases do they maintain a widespread branch network. The comparative advantages that large commercial banks have over other banks are primarily in wholesale business, securities business, commission business and foreign business. In addition, they also operate an extensive retail banking business. Like the large commercial banks, regional banks are also organised under private law and usually carry out all classical banking business. The majority of these banks operate only regionally and have no major business connections abroad.

Regional giro institutions and Land banks are the community bodies of savings banks. The 11 Land banks and regional giro institutions are, like the savings banks, public-law institutions, the guarantors of which still have unlimited liability. Unlike savings banks, Land banks and regional giro institutions are not subject to any business restrictions. Apart from some exceptions, the Land banks and regional giro institutions have no branch office networks.

\footnotetext{
${ }^{7}$ Note that the HypoVereinsbank has existed since the merger of Bayerische Hypotheken und Wechselbank and Bayerische Vereinsbank in the spring of 1998.
} 
Of all the above-mentioned banking groups, large commercial banks and Land banks have by far the largest market share of German bank lending to non-residents; they account for about $90 \%$ of all claims (see Table 1). Consequently, only these banks will be discussed below.

\section{Data sources}

The data on foreign claims of German banks, which we use in this paper, are collected in the credit register at the Deutsche Bundesbank. German credit institutions which have exceeded the threshold of $€ 1.5$ million during the reporting period are required to report all claims at the end of each quarter. They must also provide details of the type of their claims as well as of the respective borrowers. Claims are also divided into on-balance-sheet and off-balance-sheet activities. $^{8}$

The importance of off-balance-sheet activities is also acknowledged by the Bank for International Settlements (BIS, 1982), which defines country exposure as follows: "Country exposure is taken to refer to an individual bank's or banking group's exposure in its total claims on borrowers in individual foreign countries. Measures of exposure to a particular country may take account of guarantees or other factors that could shift risk to a different country from that of the borrower". Ideally, the measure of exposure should therefore cover the amount of credit risk arising from actual and potential (future) claims of all kinds. To this extent, however, information is hardly available on a significant scale. To obtain an adequate measure of banks' total credit exposure, we have therefore adjusted the raw data in several ways.

First, we consolidated all claims on emerging markets to exclude inter-office positions between a head institution and its foreign subsidiaries. ${ }^{9}$ Second, we subtracted publicly guaranteed claims from total claims to obtain a more accurate measure of banks' effective foreign exposure to credit risk. Although they account for only about $1 \%$ of total claims, they can be important for individual countries, as was the case during the Russian crisis (Russia accounted for about $30 \%$ of banks' totally guaranteed foreign claims; see Table 2).

To summarise, in comparison to other data sources the Bundesbank data allow a much better calculation of banks' true credit exposures. However, there are also some important shortcomings. There are no data available on valuation changes (for example, write-downs of non-performing loans, currency composition). Furthermore, we have no information on banks' indirect exposures to crisis countries via their lending to other commercial entities such as hedge funds (which themselves face large exposures to crisis countries).

\footnotetext{
${ }^{8}$ Off-balance-sheet items include derivatives (other than written option positions), guarantees assumed in respect of these, and other off-balance-sheet transactions (Deutsche Bundesbank, 1998). The following items are deemed not to be credit exposures: shares in other enterprises irrespective of how they are shown in the balance sheet and securities in the trading portfolio. Note that BIS data do not include off-balance-sheet claims, a shortcoming that has been noted, for instance, in van Rijckeghem and Weder (2003).

${ }^{9}$ For further details see Nestmann et al (2003).
} 


\section{Stylised facts on German bank lending during crises}

1 German bank lending is important for emerging markets.

The share of German bank lending has increased significantly during the past two decades (Figure 1). In the early 1980s, German bank lending amounted to less than $10 \%$ of total lending to BIS reporting countries. However, this share has increased since the early 1990s and amounted to about $17 \%$ at the time of the Asian and Russian financial crises. While US banks accounted for almost $40 \%$ of all lending in the early 1980s, their share has decreased significantly in the past two decades and was only marginally above German banks' share in the late 1990s.

2 German banks were significantly exposed to the two main crisis countries.

Of the four Asian crisis countries, South Korea obtained the largest share (10\% or $€ 9.7$ billion) of German bank lending to emerging markets in the pre-crisis period (Table 2). ${ }^{10}$ By the autumn of 1997 more than $20 \%$ of German exposure to developing countries was invested in crisis countries. ${ }^{11}$ Between June 1997 and June 1998 South Korea's share in banks' lending portfolios was cut significantly from $10 \%$ to $6 \%$ and has not recovered since (Table 3a). ${ }^{12}$

In September 1997 the claims of the large commercial banks and Land banks on Korea both stood at about $€ 4.7$ billion (Table $3 b$ ), for both banking groups their largest exposure to emerging markets. However, Land banks' general exposure was more concentrated on Asia than that of the large commercial banks. Thus, the crisis in Korea hit Land banks harder.

At the onset of the Russian crisis in June 1998 German banks claims on Russia amounted to $€ 9.4$ billion (see Table 2), exactly the same amount vis-à-vis South Korea before the Asian crisis. ${ }^{13}$ Between June and December 1998, the large commercial banks significantly reduced their claims on Russia by $27 \%$ ( $€ 1.6$ billion) and the Land banks by $10 \%$ ( $€ 0.36$ billion). A key difference between the Russian crisis and the Asian crisis is that the Thai crisis and even the Korean crisis were largely unexpected while the Russian crisis was at least partly so. ${ }^{14}$ Thus, Russia's share in banks' credit portfolios decreased by only 1 to 2 percentage points to about $7 \%$ and thus by less than Korea's share after the Korean crisis.

3 Developing countries' share of German bank lending appears to be remarkably stable.

Total foreign claims to developing countries have increased by almost $40 \%$, rising from $€ 86$ billion in 1997 to $€ 118$ billion in 1999 . Developing countries more or less receive a constant

\footnotetext{
${ }^{10}$ Other European banks also expanded their lending to Asia significantly in the years preceding the crisis, and claims to Asia on average accounted for $50 \%$ of their portfolio. Of this $50 \%$, South Korea accounted for about $40 \%$ (see Kaminsky and Reinhard, 2001).

${ }^{11}$ By November, the crisis had affected Thailand, Singapore, Malaysia, Indonesia, Philippines, Taiwan and Hong Kong.

${ }^{12}$ Note that claims on most Asian countries have declined; Korea's share of claims within Asia, albeit reduced by between 2 and 3 percentage points, stabilised at about $27 \%$.

${ }^{13}$ However, total exposure to Russia, ie including guaranteed claims, amounted to $€ 12$ billion in June 1998. Thus, in contrast to the situation in Korea, where no claim was publicly guaranteed in September 1997, 20\% of claims to Russia were publicly guaranteed, for example, by Hermes Buergschaften. For a definition of publicly guaranteed claims see the German Banking Act, section 14 (2) sentence 3 number 4.

${ }^{14}$ In August 1998, Russia's rating was downgraded twice on 13 and 17 August (see Kaminsky, Reinhart, Végh, 2003, p 13).
} 
share of about $11 \%$ of German bank lending per year. Thus, financial crises in emerging markets did not deter German banks from lending to developing countries. Interestingly, the Asian crisis did not lead to a reduction in claims to developing countries per se. ${ }^{15}$ Although stable in the aggregate, German bank lending varied significantly at a regional or country level, as the next subsections will show. During the Russian crisis the situation was different as German banks temporarily reduced their exposure to developing countries by $7 \%$ (€8 billion) from September 1998 to December $1998 .^{16}$

\section{During the Asian crisis, banks left Asia for the Western Hemisphere and Emerging Europe.} In the pre-crisis period both the commercial banks and Land banks had significant exposures in Asia. In June 1997, Asia accounted for $41 \%$ of bank lending to developing countries. After the crisis had unfolded in Thailand in July 1997, German banks took only a couple of months to react. Between July and December, claims on Asia even increased (Table 4). In the following six months, from December 1997 to June 1998, claims on Asia were cut by 25\% (€9.5 billion). It therefore appears that the outbreak of the Korean crisis was largely unexpected by market participants and subsequently triggered a sharp reaction from German banks, leading to large credit outflows from Asia (see Table 4). ${ }^{17}$

German banks reacted mainly by redistributing claims from Asia to other developing regions (Table 4). In the year following the outbreak of the financial crisis in Thailand, claims on the Western Hemisphere and Emerging Europe increased by $43 \%$ ( $€ 10$ billion) and $52 \%$ (€11 billion) respectively.

\section{During the Russian crisis, banks remained in Emerging Europe.}

The situation was different during the Russian crisis. Between June and December 1998, all regions experienced credit outflows (Table 4). It is astonishing that eastern Europe was much less affected by credit outflows than other emerging market regions. If anything, eastern Europe even profited from redistribution as German banks slightly increased its share in their portfolios (Table 5). However, due to such factors as geographical proximity and historical ties, Emerging Europe represents a kind of "strategic region" for German banks. Besides redistribution towards eastern Europe banks' regional portfolio composition after the Russian default in August 1998 remained fairly stable. ${ }^{18}$

6 Large commercial banks reacted more aggressively than Land banks during the crises. The large commercial banks and Land banks reacted differently in both crises. By June 1998, the large commercial banks had cut their claims on Asia by more than one-third, reducing Asia's share of their claims to developing countries to $22 \%$. The Land banks also reduced

\footnotetext{
${ }^{15}$ The Asian crisis started with the 15\%-20\% devaluation of the Thai bath on 2 July 1997 after managed floating of the bath was announced by the central bank of Thailand.

${ }^{16}$ The Russian crisis started with Russia's default on its domestic bond debt on 18 August 1998.

${ }^{17}$ In a survey by the Korean Development Institute, conducted in November 1997, "many foreign investors were optimistic about the future of the Korean economy", see Park and Song (2001), p 242. Outflows from Asia between September 1997 and June 1998: €4.4 billion from South Korea, €4 billion from Thailand, €1.7 billion from Indonesia, $€ 0.8$ billion from Taiwan and $€ 0.3$ billion from Malaysia.

${ }^{18}$ Note that the large commercial banks (LCBs) restarted lending to Asia after June 1998 while the Land banks (LBs) continued to cut back claims on Asia, a development which may still have been a consequence of the Asian crisis. In fact, it seems that the LBs' reaction to the Asian crisis took far longer than that of the LCBs. The LBs continued to reduce Asia's portfolio share until June 1999 when their portfolio share of Asia was again of the same magnitude (25\%) as LCBs'.
} 
their claims on Asia but less drastically. Claims on Asia were cut by 10 percentage points, reducing the Asian share in their portfolio to $30 \%$ of their foreign claims.

During the Russian crisis, the large commercial banks slightly reduced their exposure to Emerging Europe while the Land banks' exposure actually increased.

\section{Empirical model}

Most of the existing literature has analysed the change of bank capital during financial crises by using highly aggregated data. However, by disregarding the individual effects of lenders, important differences in the behaviour of banks may have remained undetected. Furthermore, aggregated analysis is inefficient and possibly biased as it does not make full use of the heterogeneity of the data. Instead, by using individual data on the lending flows of German banks, we are able to tackle some important issues in greater detail.

In particular, we would like to address the following questions. What were the determinants of German credit flows to emerging markets during the Asian and the Russian crises? Can it be explained by the so-called "common bank lender" effect? Did German banks respond with a general withdrawal ("wake up call" effect)? Was the reaction of German banks different from that of other banking centres, as found by van Rijckeghem and Weder (2003)? To what extent is public ownership of banks important with respect to the behaviour of banks in crises?

The data which we use to address those issues consist of information on 15 creditor banks and 40 emerging market debtor countries. ${ }^{19}$ We use the following reduced form regression equation as a starting point to explain individual bank flows: ${ }^{20}$

$$
\text { Flow }_{\mathrm{bc}}=\mathrm{c}+\alpha * \operatorname{Exp}_{\mathrm{b} 0}+\beta * \operatorname{Exp}_{\mathrm{bc}}+\gamma * \operatorname{Bank}_{\mathrm{b}}+\delta * \text { country }_{\mathrm{c}}+\mu_{b}+\mu_{c}+\varepsilon_{b c}
$$

where subscripts $b$ and $c$ stand for creditor banks and the receiving country, respectively. The subscript 0 indicates the (initial) crisis country (the country where the crisis spread from). The dependent variable is given by the flow of bank $b$ 's capital to country $c^{21}$ excluding the initial crisis country.

Our main bank specific variables are banks' exposures to the crisis country and other emerging market countries. In the context of equation (1), the "common lender" effect is measured by $\operatorname{Exp}_{\mathrm{b} 0}$, the ex ante exposure of bank $b$ to the crisis country. We expect a negative sign on the coefficient.

A negative sign on the variable Exp $\mathrm{p}_{\mathrm{bc}}$, which represents the exposure of bank $\mathrm{b}$ to country $\mathrm{c}$ reflects a general proportional drop in lending to emerging markets possibly caused by a general shift in risk perception ("wake up call”).

\footnotetext{
${ }^{19}$ See Appendix I for a complete list of the banks and countries in our sample.

${ }^{20}$ The respective crisis country (Korea, Russia) has been omitted from the regression.

${ }^{21}$ We calculate bank flows for the Asian crisis as the change in exposure between September 1997 and June 1998. For the Russian crisis, we use August 1998 until December 1998.
} 
Both $\operatorname{Exp}_{\mathrm{bc}}$ and $\operatorname{Exp}_{\mathrm{b} 0}$ refer to banks' credit exposure just at the start of the crisis. We also normalised the exposure variables with bank $b$ 's pre-crisis exposure to emerging markets in total. Furthermore, we included bank control variables such as dummies for specific banking groups and banks' size.

In addition to financial linkages, bank flows during crisis periods may be influenced by other factors as well. Therefore we control for trade competition of each country with the crisis country in common third markets. ${ }^{22}$

With respect to macroeconomic fundamentals as explanatory variables we use current account over GDP, budget balance over GDP, M2 over reserves, growth of credit to the private sector and real exchange rate appreciation, all measured before the crisis. ${ }^{23} \mathrm{We}$ expect positive signs on current account and budget balances and negative signs on the ratio of M2 to reserves, growth of credit to the private sector as well as real exchange rate appreciation. ${ }^{24}$

In order to account for a country's credit risk we also included a country's probability of default as given by its public rating as well a correlation of stock market returns as additional controls into the regression equation. The countries with a relatively large contribution to risk in banks' portfolios may suffer more than countries with lower risk. Therefore we expect negative signs on both variables.

As a starting point, we use OLS to estimate equation (1). In addition, we use panel estimation techniques. As our focus is on the behaviour of banks, we first set individual country effects to zero and assume that heterogeneity among countries can be measured by the respective control variables, and regional dummy variables. However, we will also show results for the second alternative with individual country effects allowed for and bank effects set to zero. ${ }^{25}$

Since the fixed effects model makes sense only when we exclude fixed group specific variables, ${ }^{26}$ we use the standard random effects model instead, which does not suffer from that deficiency. For example, in the setting where individual bank effects are fixed, it is not possible to determine the coefficients on banks' exposure to the crisis country as it does not vary over countries. ${ }^{27}$

\footnotetext{
${ }^{22}$ See Table 6 in the Appendix for details of the construction of this variable.

${ }^{23}$ See Table 6 in the Appendix for sources.

${ }^{24}$ This is the same set of variables included in van Rijckeghem and Weder (2003). See, for example, IMF (1999) for more details on crisis indicators.

${ }^{25}$ As a robustness check, individual bank and country effects were also determined simultaneously. It turned out, however, that the heterogeneity among the countries is not large enough to significantly influence the results.

${ }^{26}$ The fixed effects substract group means from equation (1) before applying OLS regression.

${ }^{27}$ This is due to the effect that the FE estimator subtracts "time" averages from the corresponding variable.
} 


\section{Results}

We estimated the two crises separately because the causal factors turned out to be so different that a pooling of the crises is not warranted. We first present our results for the Asian crisis, then for the Russian crisis. In the conclusion, we comment on differences and/or similarities between the two crises.

\section{Results for the Asian crisis}

Tables $7 \mathrm{a}$ and $7 \mathrm{~b}$ show the results for the Asian crisis. Column (1) shows the results of a regression including all 15 banks. We also ran separate regressions for Land banks (column 2) and for large commercial banks (column 3).

In regression (1) we observe a statistically as well as economically significant common lender effect for German banks. On average, flows to developing countries fell by almost 3 cents for each additional euro in exposure to South Korea before the crisis, holding everything else constant. The magnitude of this effect can be illustrated by multiplying the share of South Korea in a bank's portfolio by 0.03 . Exposure of Land banks to South Korea was on average $13 \%$, with the result that, on average, Land banks have reduced their exposure to the average emerging market by $0.39 \%(0.03 * 13)$ owing to the common lender effect.

There is no evidence of a "wake up call" effect during the Asian crisis. We observe that banks, rather than pulling out of developing countries indiscriminately, shifted claims from the crisis region, Asia, to emerging countries in the Western Hemisphere and Emerging Europe. ${ }^{28}$ Hence, the respective signs on the regional dummies are positive. This is consistent with the view that banks only re-assessed risks in Asia but not for emerging markets in general.

A number of macroeconomic fundamentals turn out to be statistically significant during the Asian crisis. Outflows were lower in countries that experienced large credit inflows in the year preceding the crisis and that had higher current account deficits in 1996, facts which confirm findings in the literature of early warning systems. The coefficient on budget balance over GDP is also significant, but with an unexpected sign. This can be explained by the fact that Asian countries were the only countries which ran budget surpluses in 1996. It therefore appears that the negative effect of budget discipline is spurious owing to the fact that banks decided to pull out of Asia nevertheless. Trade competition in common third markets also has a positive and significant coefficient for which we have no explanation at hand.

The large commercial banks had significantly larger outflows during the Asian crisis than the Land banks, again pointing to a larger variability of their claims. This may be due partly to the fact that Land banks enjoy a government guarantee and therefore do not react as fast as their privately owned counterparts to financial crises. The overall explanatory power of the regression is rather large with an $\mathrm{R}^{2}$ of $17 \%$.

\footnotetext{
${ }^{28}$ Note that claims to the Middle East and Africa have also increased relative to Asia, however. As total claims to these regions are well below claims on Asia, the Western Hemisphere or Emerging Europe, we do not want to interpret the coefficients of the dummy variables for Africa and the Middle East as portfolio changes.
} 
Comparing columns (2) and (3), we observe that Land banks and commercial banks behaved quite similarly except for the common lender effect, which is only significant for Land banks. One reason for that difference may be that the Land banks' exposure to South Korea was far larger in relative terms than that of the commercial banks. However, the result may also be attributed to a low variation in the sub-sample of commercial banks, which consisted of only four banks.

Summing up, we do find evidence that bank lending contributed to the transmission of the Asian crisis. However, instead of a general exodus from emerging markets, banks adjusted their emerging market portfolios by reallocating claims from Asia to the Western Hemisphere and Emerging Europe. We also find that macroeconomic fundamentals play some role in the re-distribution.

\section{Results for the Russian crisis}

Tables 8a and 8b show the regression results for the Russian crisis. As in the case of the Asian crisis, column (1) shows a regression including all 15 banks, while regressions (2) and (3) show the results for the two banking groups, Land banks and large commercial banks, separately.

Results for the Russian crisis differ sharply from the results for the Asian crisis as we can identify no (negative) common lender effect. This is rather surprising as the banks' total exposure to Russia was about the same size as their exposure to South Korea during the Asian crisis. Furthermore, we observe a positive common lender effect in regression (3) for large commercial banks. A higher exposure to Russia leads to larger inflows to other emerging markets holding other variables constant. This somehow counterintuitive result is in line with findings in van Rijckeghem and Weder (2003): when including German banks in their sample, they also find a positive and significant common lender effect for different banking centres. ${ }^{29}$ However, their presumption that guarantees were the driving force behind German banks' continued lending during the Russian crisis cannot explain our results as claims exclude guarantees. ${ }^{30}$ Thus, other factors seem to have determined German lending, and more research is needed to explain this behaviour.

In contrast to the Asian crisis, there was a very large and highly significant wake up call for German banks. We observe a general outflow from emerging markets of about $18 \%$ of initial exposures. ${ }^{31}$ Thus, as far as the evidence of that effect is concerned, German banks in the present study do not differ from other banking centres, as found in van Rijckeghem and Weder (2003). In fact, the proportional outflow is more than twice as large as what van

\footnotetext{
${ }^{29}$ Note that the coefficient is also positive if German banks are excluded but remains statistically insignificant. Other banking centres therefore do not seem to differ that much with respect to the common lender effect of German banks.

${ }^{30}$ Several differences between German banks analysed in van Rijckeghem and Weder (2003) and in this study should be noted. First, we look at claims to 40 instead of 30 emerging markets, second, banks' exposure to Russia in our sample is only about half the size of that for BIS reporting banks [see Table 3a] and, third, in our data only $20 \%$ [2.5/(9.4+2.5)] of claims are publicly guaranteed in June 1998 instead of 50\%-60\%, as assumed by van Rijckeghem and Weder for the BIS reporting banks.

${ }^{31}$ Note that aggregated BIS data on German banks show that, despite a large exposure to Russia, German banks had on average a positive inflow to emerging markets. See van Rijckeghem and Weder (2003, p 517).
} 
Rijckeghem and Weder (2003) found for different banking centres, a finding which may in part be attributed to the fact that we consider claims excluding guarantees.

Macroeconomic conditions did not seem to matter for banks' credit flows as none of the macro controls is significant. Surprisingly, Emerging Europe, which has strong economic links to Russia, experienced fewer portfolio outflows than Asia. Furthermore, there was no difference in flows between Emerging Europe and the Western Hemisphere that is not explained by other variables in the regression. ${ }^{32}$

Large commercial banks' flows do not seem to differ from those of the Land banks in the Russian crisis as the dummy on commercial banks is not significant. The variation in flows is surprisingly well explained by our model, the $\mathrm{R}^{2}$ for (1) is $24 \%$.

Separate regressions for Land banks (2) and large commercial banks (3) differ only on the common lender effect variable. One thing worth noting is that the Land banks pulled out of Asia and the commercial banks did not. That may be due to the fact that the Land banks were still adjusting their portfolios in response to the Asian crisis as they did not reduce claims as drastically as the large banks did during the Asian crisis (Tables 4\&5).

Summing up, we find strong evidence of a wake-up call effect during the Russian crisis. This can be interpreted as an increase in general risk aversion towards emerging markets at that time. The increase in general risk aversion can be explained due to two factors. First, banks which had faced large losses in the Asian crisis did not want to experience this in the Russian crisis again. Second, the LTCM crisis, which occurred shortly after the Russian crisis, had also contributed to a rise in general risk aversion towards emerging markets. Other factors such as macroeconomic conditions or banks' exposure to Russia did not seem to matter for banks' lending decisions.

\section{Sensitivity of regression results}

We tested the robustness of our results in several ways. First, we checked our results using flows adjusted for currency fluctuations. Second, we applied estimation techniques other than OLS, in particular, panel data estimations allowing for group specific random and fixed effects, respectively. Third, we added additional variables to our baseline specification in (1).

\section{Sensitivity tests for the Asian crisis}

First, we check (1) for cross currency valuation effects since the stock of claims is reported only in Euro. For this purpose, we use additional information on the currency composition of the total of German banks and their foreign branches and subsidiaries to correct for exchange rate shifts. The correction is done under the (crude) assumption that all banks had the same currency composition as the average bank with respect to a specific country. Looking at column (4), we observe that results are almost the same as in (1). Note that the number of observations drops from 367 to 336 as data on the currency composition for five borrower countries are not available. ${ }^{33}$ Second, column (5) displays results of a regression where

\footnotetext{
${ }^{32}$ As in the Asian crisis, we do not interpret the coefficients on the dummy variables for the Middle East and Africa as portfolio reallocation as their total shares in banks' portfolios are rather small.

${ }^{33}$ These countries are: Estonia, Lithuania, Latvia, Costa Rica and Uruguay.
} 
macroeconomic variables, regional dummies as well as the trade competition variable are replaced by a country dummy. Again, with respect to the other variables, results hardly differ from those of regression (1). The common lender effect increases marginally in size and significance while the dummy for LCBs remains almost unchanged. Note that the $\mathrm{R}^{2}$ has increased to $25 \%$ instead of $17 \%$. Thus, although our country specific variables do capture a good part of cross country differences, they cannot explain country heterogeneity to the full extent.

Regression (6) shows a random effects estimation allowing for bank specific effects and country specific effects set to zero. Although the Breusch-Pagan test shows that the random effects model is more appropriate than pooled OLS, the coefficients in (1) and (6) are almost the same for all variables considered. The same holds true for regression (7) where we allow for country specific effects (and individual bank effects set to zero). Thus, neither bank nor country specific effects appear to play an important economic role. ${ }^{34}$

In (8) to (10) we include additional variables that may influence banks' lending decisions, as described in sections 2 and 5. In (8) we include the logarithm of total assets in our baseline specification as a proxy for bank size. Bank size does not appear to play a role. Furthermore, adding bank size hardly alters the estimated coefficients of other variables. Regression (9) includes another country specific variable, the correlation of stock market returns with South Korea prior to the crisis, but this does not have a significant impact on bank flows either. In (9), coefficients of the other explanatory variables change slightly; the common lender effect, for instance, increases somewhat in this specification. The last regression (10) includes the probability of default (PD) of a country instead of macroeconomic variables, assuming that the PD is to a large extent influenced by prevailing macroeconomic conditions. ${ }^{35}$ Again, the coefficient of the common lender variable increases in size and this time in significance as well. The PD itself, however, remains insignificant.

\section{Sensitivity tests for the Russian crisis}

We tested the sensitivity of the results for the Russian crisis in the same way as for the Asian crisis.

As can be seen from column (4), currency adjustments hardly alter the results of (1). We also replaced country specific variables by country dummies (regression 5). The increase of $\mathrm{R}^{2}$ from $24 \%$ to $34 \%$ in comparison to (1) implies that our country specific variables do not fully capture all country specific effects. Note that the coefficient on the "wake up call" variable increases slightly to 0.21 .

\footnotetext{
${ }^{34}$ To further cross-check our results, we also ran a regression with country specific fixed effects (a regression with fixed effects for banks is not feasible for the reasons described in section (5). As before, results on the coefficients are very close to the OLS results in column (1); however, the explanatory power decreases to just $0.3 \%$. Note that the Hausman test for fixed versus random effects indicates anyway that the random effects model should be applied.

${ }^{35}$ For the construction of this variable see Table 6 in the Appendix.
} 
Columns (6) and (7) of Table 8 show the results of two random effects estimators for the baseline specification with bank specific effects and country specific effects, respectively. ${ }^{36}$ Again, as in the regressions for the Asian crisis, the Breusch-Pagan test for random effects is significant in (6) but not in (7). The fit of (6) and (7) is approximately the same as in (1). With respect to the coefficients in (6) and (7), we observe that they do not differ significantly from our pooled OLS regression (1) either. The magnitude of the "wake up call" variable, for instance, remains unchanged at $18 \%$.

As for the Asian crisis, we analysed different specifications of our baseline regression by adding additional variables (columns 8 to 10). However, none of the additional variables turned out to be significant. The "wake up call" variable remained the only important variable in all regressions.

\footnotetext{
36 The Hausman test for fixed versus random effects is not significant for either (4) or (5). Results for a "country" fixed effects regression (not shown) are also hardly different. The coefficient of the wake up call variable increases slightly to $21 \%$, and the significance level remains almost unchanged at $22 \%$.
} 


\section{Summary and conclusion}

The aim of this paper is to analyse the pattern of German bank lending during financial crises. The following are our findings.

First, emerging markets received a surprisingly stable share of German foreign lending between 1997 and 1999 despite the fact that German banks were significantly exposed to crisis countries.

Second, the behaviour of German banks was fundamentally different in the two crisis episodes considered. While they mainly shifted emerging markets portfolios after the outbreak of the Asian crisis, they reduced their emerging markets investments across the board following the Russian crisis. During the Asian crisis, banks with a larger exposure to South Korea withdrew from emerging markets with deteriorating macroeconomic conditions and lent ceteris paribus more to countries with better macroeconomic conditions. However, a large part of the re-distribution may also be attributed to the fact that banks re-assessed risks for the different regions. By contrast, neither banks' exposure to Russia nor macroeconomic conditions or regional considerations played a role in banks' lending decisions during the Russian crisis, where all emerging countries across the board suffered from the withdrawal of German banks.

Third, the large commercial banks and Land banks appear to differ in their behaviour during the crises. For instance, the large commercial banks reacted more aggressively than the Land banks during the Asian crisis. Differences are not as pronounced during the Russian crisis.

Our findings underline the need for credit risk and early warning system models to incorporate a crisis country's external effects on other borrowers. Thus, it does not suffice for banks to assess the credit risks of each country individually. Instead, banks also need to detect other channels through which crises propagate. In particular, it is essential to assess the mix of investors exposed to a crisis country. Banks should also be aware of the fact that a country's creditworthiness can deteriorate very fast when investors suddenly change their perceptions towards emerging markets altogether in the face of problems in one of the emerging market countries. Since individual banks do not have full access to individual data of other banks, the development of such early warning system models is also an important issue for bank supervisors. 


\section{Appendix}

\section{Corporate banking groups and countries in the sample}

\section{$\underline{\text { Large commercial banks }}$}

Bayerische Hypo- und Vereinsbank München AG Konzern

Commerzbank AG Frankfurt Konzern

Deutsche Bank AG Frankfurt Konzern

Dresdner Bank AG Frankfurt Konzern

\section{$\underline{\text { Land banks }}$}

Bankgesellschaft Berlin AG Konzern

Bayern LB Holding AG München Gruppe

Hamburgische Landesbank Girozentrale Hamburg Gruppe

Landesbank Baden Württemberg Stuttgart Gruppe

Landesbank Nordrhein Westfahlen AG Düsseldorf Gruppe

Landesbank Rheinland Pfalz Girozentrale Mainz Gruppe

Landesbank Sachsen Girozentrale Leipzig Gruppe

Landesbank Schleswig Holstein Kiel Gruppe

Norddeutsche Landesbank GZ Hannover Gruppe

Sparkassen und Giroverband Hessen Thüringen Frankfurt Gruppe

Sparkassen und Giroverband Saarbrücken Saar Gruppe

\section{$\underline{\text { Developing countries }}$}

Argentina, Bolivia, Brazil, Chile, China, Colombia, Costa Rica, Côte d'Ivoire, Ecuador,

Egypt, Estonia, Ghana, Hungary, India, Indonesia, Israel, Jordan, Kenya, Latvia, Lithuania, Malaysia, Mexico, Morocco, Nigeria, Pakistan, Paraguay, Peru, Philippines, Poland,

Romania, Russia, Slovak Republic, Slovenia, South Africa, South Korea, Thailand, Tunisia, Turkey, Uruguay, Venezuela. 


\section{Figures and tables}

Figure 1. German and US banks' claims as a percentage of total claims to developing countries

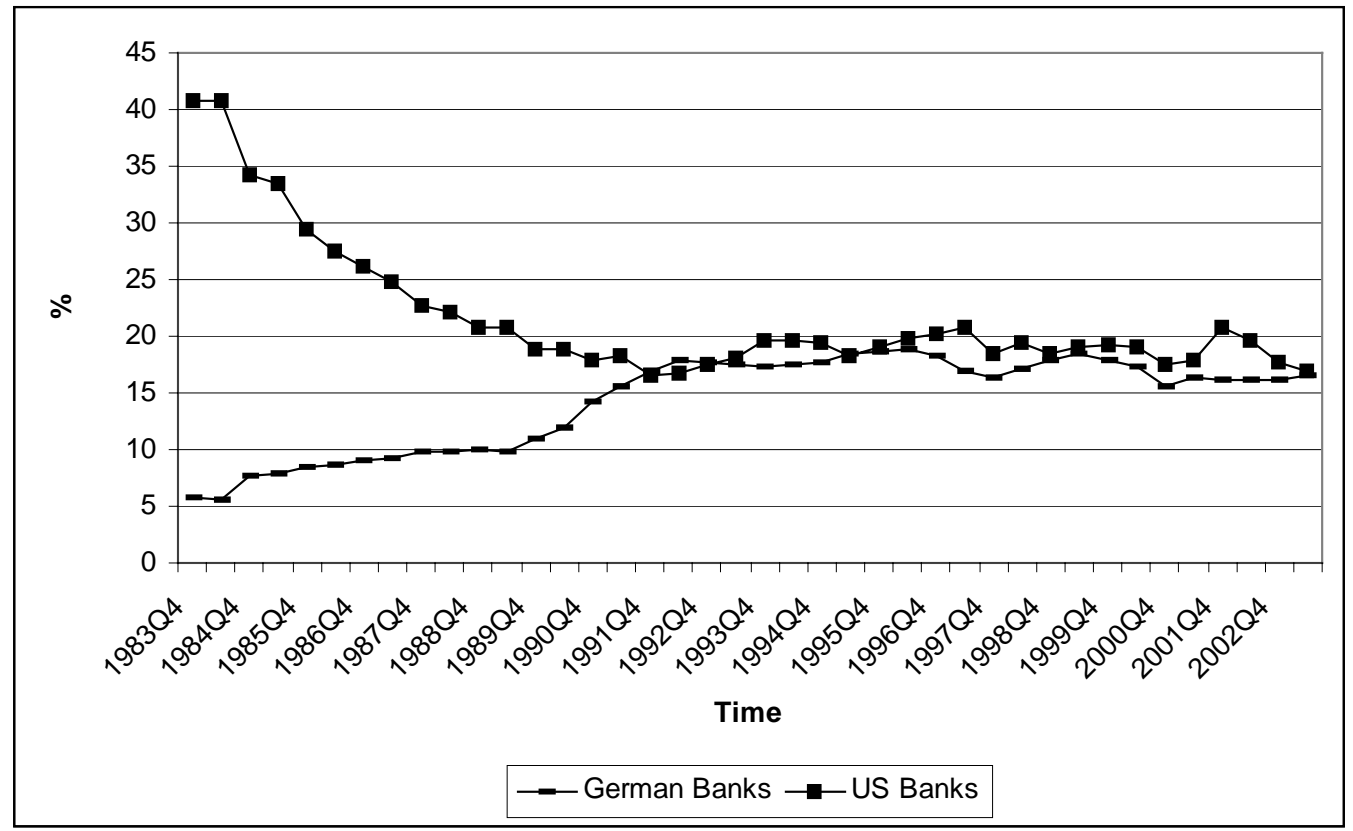

Sources: Total foreign claims by nationality of reporting bank (historical time series), Consolidated Banking Statistics, Bank for International Settlement (BIS). Data are semi-annual, e.g. 1983Q4 refers to December 1983.

Table 1. Foreign claims ${ }^{\#}$ of German banks from 1997 to 1999

\begin{tabular}{ccccccc}
\hline Time & $\begin{array}{c}\text { Total claims } \\
\text { All Banks } \\
(€ \text { billion) }\end{array}$ & $\begin{array}{c}\text { Total claims } \\
\text { of LCBs* and } \\
\text { LBs* } \\
(€ \text { billion) }\end{array}$ & $\begin{array}{c}\text { Claims of } \\
\text { LCBs* and } \\
\text { LBs* on } \\
\text { developing } \\
\text { countries } \\
(€ \text { billion) }\end{array}$ & $\begin{array}{c}\text { Claims of } \\
\text { LCBs* and } \\
\text { LBs* on } \\
\text { developing } \\
\text { countries } \\
(\%)\end{array}$ & $\begin{array}{c}\text { Claims of } \\
\text { LBCs* on } \\
\text { developing } \\
\text { countries } \\
(€ \text { billion) }\end{array}$ & $\begin{array}{c}\text { Claims of } \\
\text { LBs* on } \\
\text { developing } \\
\text { countries } \\
(€ \text { billion) }\end{array}$ \\
\hline 199703 & 864 & 783 & 86 & 11.0 & 471 & 312 \\
199706 & 893 & 809 & 93 & 11.5 & 481 & 328 \\
199709 & 938 & 848 & 97 & 11.4 & 499 & 349 \\
199712 & 1,000 & 907 & 107 & 11.8 & 523 & 384 \\
199803 & 1,124 & 1,023 & 108 & 10.5 & 605 & 417 \\
199806 & 1,125 & 1,022 & 112 & 11.0 & 579 & 443 \\
199809 & 1,198 & 1,089 & 112 & 10.3 & 649 & 440 \\
199812 & 1,035 & 924 & 104 & 11.3 & 506 & 419 \\
199903 & 1,124 & 1,003 & 114 & 11.4 & 560 & 443 \\
199906 & 1,220 & 1,094 & 118 & 10.8 & 629 & 465
\end{tabular}

Source: Deutsche Bundesbank, authors. \# All claims exclude guarantees. * LCB stands for "Large commercial bank", LB stands for "Land bank". See Appendix I for a detailed list of banks included in our sample. 
Table 2. Guaranteed ${ }^{+}$foreign claims of LCBs* and LBs* from 1997 to 1999

\begin{tabular}{ccccccc}
\hline Time & $\begin{array}{c}\text { Guaranteed } \\
\text { claims of } \\
\text { LCBs* } \\
(€ \text { billion })\end{array}$ & $\begin{array}{c}\text { Guaranteed } \\
\text { claims of } \\
\text { LBs* } \\
(€ \text { billion) }\end{array}$ & $\begin{array}{c}\text { Guaranteed } \\
\text { claims of } \\
\text { LCBs* } \\
\text { on Russia } \\
(€ \text { billion) }\end{array}$ & $\begin{array}{c}\text { Guaranteed } \\
\text { claims of } \\
\text { LBs* } \\
\text { on Russia } \\
(€ \text { billion) }\end{array}$ & $\begin{array}{c}\text { Guaranteed } \\
\text { claims of } \\
\text { LCBs* } \\
\text { on South } \\
\text { Korea } \\
(€ \text { billion) }\end{array}$ & $\begin{array}{c}\text { Guaranteed } \\
\text { claims of } \\
\text { LBs* } \\
\text { on South } \\
\text { Korea } \\
(€ \text { billion })\end{array}$ \\
\hline 199703 & 4.1 & 2.8 & 1.4 & 1.1 & 0 & 0 \\
199706 & 4.5 & 2.8 & 1.6 & 1.1 & 0 & 0 \\
199709 & 4.3 & 2.9 & 1.7 & 1.3 & 0 & 0 \\
199712 & 4.6 & 2.9 & 1.7 & 1.0 & 0 & 0 \\
199803 & 4.0 & 3.4 & 1.5 & 1.0 & 0.003 & 0 \\
199806 & 4.2 & 2.4 & 1.6 & 0.9 & 0.003 & 0 \\
199809 & 3.8 & 2.7 & 1.3 & 1.0 & 0.014 & 0 \\
199812 & 4.2 & 3.5 & 1.2 & 1.2 & 0.023 & 0 \\
199903 & 5.1 & 3.7 & 1.4 & 1.2 & 0.023 & 0.017 \\
199906 & 4.1 & 3.9 & 1.2 & 1.3 & 0.045 & 0.012 \\
\hline
\end{tabular}

Source: Deutsche Bundesbank, authors. + Guarantees include, for example, "Hermes Buergschaften"; see German Banking Act, section 14 (2) sentence 3 number 4 for an exact definition of guarantees. * LCB stands for "Large commercial bank", LB stands for "Land bank". See Appendix I for a detailed list of banks included in our sample.

Table 3a. Exposure ${ }^{\#}$ of LCBs* and LBs* to South Korea and Russia from 1997 to 1999

\begin{tabular}{ccccc}
\hline Time & $\begin{array}{c}\text { Claims on South } \\
\text { Korea } \\
(€ \text { billion })\end{array}$ & $\begin{array}{c}\text { Claims on } \\
\text { Russia } \\
(€ \text { billion })\end{array}$ & $\begin{array}{c}\text { Claims on South } \\
\text { Korea as a } \\
\text { percentage of } \\
\text { total foreign } \\
\text { claims on } \\
\text { developing } \\
\text { countries }\end{array}$ & $\begin{array}{c}\text { Claims on } \\
\text { Russia as a } \\
\text { percentage of } \\
\text { total foreign } \\
\text { claims on } \\
\text { developing } \\
\text { countries }\end{array}$ \\
\hline 199703 & 9.7 & 4.6 & 11.2 & 5.3 \\
199706 & 9.7 & 5.4 & 10.4 & 5.8 \\
199709 & 9.4 & 6.1 & 9.7 & 6.3 \\
199712 & 8.8 & 7.5 & 8.3 & 7.0 \\
199803 & 7.5 & 8.5 & 7.0 & 7.9 \\
199806 & 6.9 & 9.4 & 6.2 & 8.3 \\
199809 & 6.6 & 8.6 & 5.9 & 7.7 \\
199812 & 6.3 & 7.4 & 6.1 & 7.1 \\
199903 & 7.5 & 8.1 & 6.5 & 7.1 \\
199906 & 6.7 & 8.1 & 5.7 & 6.9 \\
\hline
\end{tabular}

Source: Deutsche Bundesbank, authors. \# All claims exclude guarantees. * LCB stands for "Large commercial bank", LB stands for "Land bank". See Appendix I for a detailed list of banks included in our sample. 


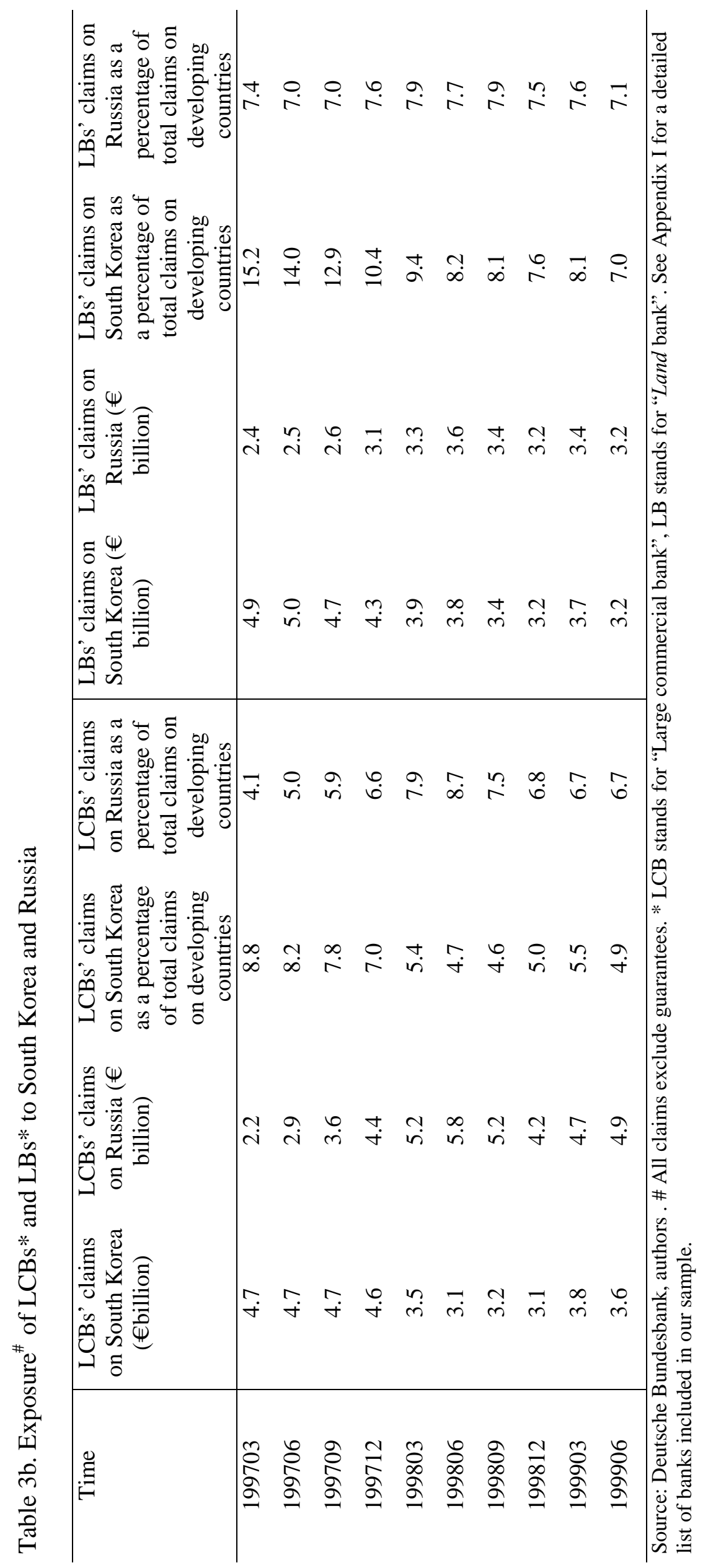


Table 4. Total regional claims ${ }^{\#}$ of LCBs* and LBs* in $€$ billion from 1997 to 1999

\begin{tabular}{|c|c|c|c|c|c|}
\hline Total & Asia & Africa & Middle East & Western Hemisphere & Emerging Europe \\
\hline 199706 & 38.3 & 4.9 & 5.8 & 22.9 & 21.2 \\
\hline 199709 & 38.0 & 5.4 & 6.0 & 23.8 & 23.7 \\
\hline 199712 & 39.5 & 5.4 & 7.4 & 27.9 & 26.4 \\
\hline 199803 & 34.4 & 6.1 & 6.5 & 31.3 & 29.5 \\
\hline 199806 & 29.0 & 10.3 & 7.9 & 32.8 & 32.4 \\
\hline 199809 & 29.2 & 10.0 & 7.8 & 33.0 & 31.8 \\
\hline 199812 & 26.8 & 9.5 & 7.6 & 28.8 & 31.4 \\
\hline 199903 & 29.3 & 9.5 & 8.8 & 32.7 & 34.2 \\
\hline 199906 & 29.8 & 10.2 & 9.8 & 32.9 & 35.5 \\
\hline LCBs & Asia & Africa & Middle East & Western Hemisphere & Emerging Europe \\
\hline 199706 & 23.0 & 3.6 & 4.0 & 15.4 & 11.7 \\
\hline 199709 & 23.3 & 4.1 & 4.0 & 15.8 & 13.1 \\
\hline 199712 & 23.3 & 4.1 & 5.5 & 18.9 & 14.0 \\
\hline 199803 & 18.9 & 4.7 & 4.4 & 21.2 & 16.4 \\
\hline 199806 & 14.7 & 7.2 & 5.1 & 21.9 & 17.3 \\
\hline 199809 & 16.9 & 7.0 & 5.3 & 23.3 & 16.6 \\
\hline 199812 & 15.1 & 6.6 & 5.0 & 18.9 & 16.2 \\
\hline 199903 & 16.8 & 6.9 & 5.2 & 21.6 & 18.5 \\
\hline 199906 & 18.1 & 7.6 & 6.1 & 21.6 & 19.4 \\
\hline LBs & Asia & Africa & Middle East & Western Hemisphere & Emerging Europe \\
\hline 199706 & 15.3 & 1.3 & 1.8 & 7.4 & 9.5 \\
\hline 199709 & 14.7 & 1.3 & 2.0 & 7.9 & 10.6 \\
\hline 199712 & 16.1 & 1.3 & 2.0 & 9.0 & 12.5 \\
\hline 199803 & 15.4 & 1.4 & 2.1 & 10.1 & 13.1 \\
\hline 199806 & 14.2 & 3.1 & 2.8 & 10.9 & 15.1 \\
\hline 199809 & 12.4 & 3.0 & 2.5 & 9.6 & 15.2 \\
\hline 199812 & 11.8 & 2.9 & 2.6 & 9.9 & 15.2 \\
\hline 199903 & 12.5 & 2.6 & 3.6 & 11.1 & 15.6 \\
\hline 199906 & 11.8 & 2.6 & 3.7 & 11.3 & 16.1 \\
\hline
\end{tabular}

Source: Deutsche Bundesbank, authors . \# All claims exclude guarantees. * LCB stands for "Large commercial bank", LB stands for "Land bank". See Appendix I for a detailed list of banks included in our sample. 
Table 5. Regional claims of LCBs* and LBs* as a percentage of claims ${ }^{*}$ on developing countries

\begin{tabular}{|c|c|c|c|c|c|}
\hline Total & Asia & Africa & Middle East & Western Hemisphere & Emerging Europe \\
\hline 199706 & 41.2 & 5.2 & 6.2 & 24.6 & 22.8 \\
\hline 199709 & 39.2 & 5.6 & 6.2 & 24.6 & 24.4 \\
\hline 199712 & 37.0 & 5.1 & 7.0 & 26.2 & 24.8 \\
\hline 199803 & 31.9 & 5.6 & 6.0 & 29.0 & 27.4 \\
\hline 199806 & 25.8 & 9.2 & 7.0 & 29.2 & 28.8 \\
\hline 199809 & 26.1 & 8.9 & 7.0 & 29.5 & 28.5 \\
\hline 199812 & 25.8 & 9.1 & 7.3 & 27.7 & 30.2 \\
\hline 199903 & 25.6 & 8.3 & 7.7 & 28.6 & 29.9 \\
\hline 199906 & 25.2 & 8.6 & 8.3 & 27.8 & 30.0 \\
\hline LCBs & Asia & Africa & Middle East & Western Hemisphere & Emerging Europe \\
\hline 199706 & 39.9 & 6.3 & 6.9 & 26.7 & 20.2 \\
\hline 199709 & 38.6 & 6.8 & 6.7 & 26.3 & 21.6 \\
\hline 199712 & 35.5 & 6.2 & 8.3 & 28.7 & 21.3 \\
\hline 199803 & 28.9 & 7.2 & 6.7 & 32.2 & 25.0 \\
\hline 199806 & 22.2 & 10.8 & 7.7 & 33.1 & 26.1 \\
\hline 199809 & 24.4 & 10.2 & 7.7 & 33.7 & 24.0 \\
\hline 199812 & 24.4 & 10.7 & 8.0 & 30.7 & 26.2 \\
\hline 199903 & 24.3 & 10.0 & 7.5 & 31.3 & 26.9 \\
\hline 199906 & 24.8 & 10.5 & 8.4 & 29.6 & 26.7 \\
\hline LBs & Asia & Africa & Middle East & Western Hemisphere & Emerging Europe \\
\hline 199706 & 43.4 & 3.6 & 5.1 & 21.0 & 26.9 \\
\hline 199709 & 40.2 & 3.5 & 5.4 & 21.8 & 29.1 \\
\hline 199712 & 39.4 & 3.3 & 4.8 & 22.1 & 30.4 \\
\hline 199803 & 36.6 & 3.2 & 5.0 & 24.1 & 31.1 \\
\hline 199806 & 30.9 & 6.8 & 6.0 & 23.6 & 32.7 \\
\hline 199809 & 29.0 & 6.9 & 5.8 & 22.6 & 35.7 \\
\hline 199812 & 27.8 & 6.8 & 6.2 & 23.4 & 35.9 \\
\hline 199903 & 27.5 & 5.7 & 7.9 & 24.4 & 34.4 \\
\hline 199906 & 25.9 & 5.7 & 8.1 & 25.0 & 35.4 \\
\hline
\end{tabular}

Source: Deutsche Bundesbank, authors . \# All claims exclude guarantees. * LCB stands for "Large commercial bank", LB stands for "Land bank". See Appendix I for a detailed list of banks included in our sample. 
Table 6. Description of variables

\begin{tabular}{ll} 
Variable & Description \\
\hline Flows & For Asian crisis: stock of claims by country in 1998, end \\
& of second quarter minus stock in 1997, end of third \\
& quarter over stock of claims on all emerging markets in \\
& 1997, end of third quarter (in $€$ ). \\
& For Russian crisis: stock of claims by country in 1998, \\
& end of fourth quarter minus stock in 1998, end of second \\
& quarter over stock of claims on all emerging markets in \\
& 1998, end of second quarter (in $€)$.
\end{tabular}

Common bank lender For Asian crisis: stock of claims on South Korea in 1997, end of third quarter over stock of claims on all emerging markets, 1997, end of third quarter (in €).

Source

Deutsche Bundesbank, Credit register for loans of three million Deutsche Mark or more

For Russian crisis: stock of claims on Russia in 1998, end of second quarter over stock of claims on all emerging markets in 1998, end of second quarter (in €).

Wake up call For Asian crisis: stock of claims by country in 1997, end of third quarter over stock of claims on all emerging markets, 1997, end of third quarter (in €).

For Russian crisis: stock of claims by country in 1998 , end of second quarter over stock of claims on all emerging markets in 1998, end of second quarter (in $€$ ).

Log assets Logarithm of banks' total assets (in $€$ ) in accordance with section 25 (2) of the German Banking Act.

Deutsche Bundesbank, Credit register for loans of three million Deutsche

Mark or more

Deutsche Bundesbank, Credit register for loans of three million Deutsche Mark or more

Deutsche Bundesbank, (Bakis Database) IMF, International Financial Statistics IMF, International Financial Statistics IMF, International Financial Statistics IMF, International Financial Statistics Glick and Rose (1999) own calculations using IMF, International Financial Statistics Glick and Rose (1999), own calculations for South Korea and Russia using Direction of Trade Statistics, IMF $\mathrm{x} 0$ : All exports to crisis country 0 . xi: All exports to country i.

Probability of default Using long-term foreign currency ratings for sovereigns, sovereign probability of default rates are obtained by merging sovereign ratings to one year corporate default rates. For Asian crisis: third quarter 1997, for Russian crisis: second quarter 1998

Correlation of stock market returns

Regional dummies
Monthly correlation of countries' stock market returns with stock market return in crisis country over the three years preceding the crises.

Dummy for regions in accordance with IMF classification: Asia, Africa, Middle East, Western

Hemisphere, Emerging Europe

Dummy for large commercial banks: 1, for Land banks: 0 Authors
Morgan Stanley Capital

International on

Datastream

IMF 


\section{Regression results}

Table 7a. Results for Asian crisis

\begin{tabular}{|c|c|c|c|c|c|}
\hline & $\begin{array}{l}\text { (1) } \\
\text { Baseline } \\
\text { specification } \\
\text { All banks } \\
\text { OLS }\end{array}$ & $\begin{array}{l}\text { (2) } \\
\text { Baseline } \\
\text { specification } \\
\text { Land banks } \\
\text { OLS }\end{array}$ & $\begin{array}{l}\text { (3) } \\
\text { Baseline } \\
\text { specification } \\
\text { Commercial } \\
\text { banks } \\
\text { OLS }\end{array}$ & $\begin{array}{l}\text { (4) } \\
\text { Baseline } \\
\text { specification } \\
\text { All banks } \\
\text { OLS } \\
\text { Flows } \\
\text { adjusted for } \\
\text { currency } \\
\text { fluctuations }\end{array}$ & $\begin{array}{l}\text { (5) } \\
\text { (1) with country } \\
\text { dummies } \\
\text { All banks } \\
\text { OLS }\end{array}$ \\
\hline Common L & $\begin{array}{l}-0.0289^{* *} \\
(0.015)\end{array}$ & $\begin{array}{l}-0.032^{*} \\
(0.018)\end{array}$ & $\begin{array}{l}-0.015 \\
(0.024)\end{array}$ & $\begin{array}{l}-0.031 * * \\
(0.0155)\end{array}$ & $\begin{array}{l}-0.031 * * \\
(0.015)\end{array}$ \\
\hline Wake up call & $\begin{array}{l}-0.0193 \\
(0.057)\end{array}$ & $\begin{array}{l}-0.0009 \\
(0.062)\end{array}$ & $\begin{array}{l}-0.092 \\
(0.129)\end{array}$ & $\begin{array}{l}-0.037 \\
(0.061)\end{array}$ & $\begin{array}{l}-0.066 \\
(0.075)\end{array}$ \\
\hline Credit gr & $\begin{array}{l}-0.0001 * * * \\
(0.00003)\end{array}$ & $\begin{array}{l}-0.0001 * * \\
(0.00004)\end{array}$ & $\begin{array}{l}-0.0001 * \\
(0.00005)\end{array}$ & $\begin{array}{l}-0.0001 * * * \\
(0.00004)\end{array}$ & --- \\
\hline CAoGDP & $\begin{array}{l}0.076 * * * \\
(0.027)\end{array}$ & $\begin{array}{l}0.060 * \\
(0.033)\end{array}$ & $\begin{array}{l}0.111 * * \\
(0.048)\end{array}$ & $\begin{array}{l}0.079 * * * \\
(0.030)\end{array}$ & --- \\
\hline BBoGDP & $\begin{array}{l}-0.102 * * * \\
(0.038)\end{array}$ & $\begin{array}{l}-0.105^{* *} \\
(0.044)\end{array}$ & $\begin{array}{l}-0.097 \\
(0.074)\end{array}$ & $\begin{array}{l}-0.118^{* * * *} \\
(0.0427)\end{array}$ & --- \\
\hline M2oRES & $\begin{array}{l}0.0001 \\
(0.0001)\end{array}$ & $\begin{array}{l}0.00003 \\
(0.00008)\end{array}$ & $\begin{array}{l}0.0003 * * \\
(0.0001)\end{array}$ & $\begin{array}{l}0.00007 \\
(0.00007)\end{array}$ & --- \\
\hline Trade comp & $\begin{array}{l}0.021 * * \\
(0.011)\end{array}$ & $\begin{array}{l}0.019 \\
(0.014)\end{array}$ & $\begin{array}{l}0.025 \\
(0.019)\end{array}$ & $\begin{array}{l}0.020 * \\
(0.012)\end{array}$ & --- \\
\hline Africa & $\begin{array}{l}0.010^{*} \\
(0.005)\end{array}$ & $\begin{array}{l}0.006 \\
(0.006)\end{array}$ & $\begin{array}{l}0.018 * * \\
(0.008)\end{array}$ & $\begin{array}{l}0.010^{*} \\
(0.004)\end{array}$ & --- \\
\hline ME & $\begin{array}{l}0.012 * * * \\
(0.004)\end{array}$ & $\begin{array}{l}0.009 \\
(0.005)^{* *}\end{array}$ & $\begin{array}{l}0.016^{* * *} \\
(0.007)\end{array}$ & $\begin{array}{l}0.010 * * * \\
(0.003)\end{array}$ & --- \\
\hline WH & $\begin{array}{l}0.019 * * * \\
(0.004)\end{array}$ & $\begin{array}{l}0.016 * * * \\
(0.005)\end{array}$ & $\begin{array}{l}0.023 * * * \\
(0.007)\end{array}$ & $\begin{array}{l}0.018 * * * \\
(0.004)\end{array}$ & --- \\
\hline $\mathrm{EE}$ & $\begin{array}{l}0.024 * * * \\
(0.006)\end{array}$ & $\begin{array}{l}0.020 * * \\
(0.008)\end{array}$ & $\begin{array}{l}0.030^{* *} \\
(0.013)\end{array}$ & $\begin{array}{l}0.024 * * * \\
(0.007)\end{array}$ & --- \\
\hline Com banks & $\begin{array}{l}-0.0043^{* * *} \\
(0.0021)\end{array}$ & --- & --- & $\begin{array}{l}-0.004^{*} \\
(0.0024)\end{array}$ & $\begin{array}{l}-0.0041^{*} \\
(0.0022)\end{array}$ \\
\hline $\mathrm{R}^{2}$ & 0.17 & 0.15 & 0.26 & 0.18 & 0.25 \\
\hline $\mathrm{N}$ & 367 & 234 & 133 & 336 & 367 \\
\hline
\end{tabular}

Notes. Dependent variable: bank flows between September 1997 and June 1998 normalised by each bank's total exposure to developing countries. $*, * *, * * *$ refer to $10 \%, 5 \%$ and $1 \%$ level of significance, respectively. Constant not reported. Standard errors in parentheses. OLS standard errors are corrected for heteroscedasticity using the Huber/White/sandwich estimator of variance. Reference region is Asia.

Reference banking group is Land banks. Exchange rate appreciation is omitted owing to high correlation with credit growth. Note that the sample size in (4) is smaller than in (1) because data on currency composition of claims was not available for five countries. Coefficients for the country dummy variables in (5) are not reported. For construction of variables see Table 6. 
Table 7b. Results for Asian crisis

\begin{tabular}{|c|c|c|c|c|c|}
\hline & $\begin{array}{l}\text { (6) } \\
\text { Baseline } \\
\text { specification } \\
\text { All banks } \\
\text { RE (banks) }\end{array}$ & $\begin{array}{l}\text { (7) } \\
\text { Baseline } \\
\text { specification } \\
\text { All banks } \\
\text { RE (country) }\end{array}$ & $\begin{array}{l}\text { (8) } \\
\text { (1) including } \\
\text { log assets } \\
\text { All banks } \\
\text { OLS }\end{array}$ & $\begin{array}{l}\text { (9) } \\
\text { (1) including } \\
\text { stock corr } \\
\text { All banks } \\
\text { OLS }\end{array}$ & $\begin{array}{l}\text { (10) } \\
\text { (1) including } \\
\text { PD } \\
\text { All banks } \\
\text { OLS }\end{array}$ \\
\hline Common L & $\begin{array}{l}-0.0285^{*} \\
(0.017)\end{array}$ & $\begin{array}{l}-0.0291 * \\
(0.016)\end{array}$ & $\begin{array}{l}-0.0291 * * \\
(0.015)\end{array}$ & $\begin{array}{l}-0.033^{*} \\
(0.019)\end{array}$ & $\begin{array}{l}-0.037 * * \\
(0.017)\end{array}$ \\
\hline Wake up call & $\begin{array}{l}-0.0192 \\
(0.033)\end{array}$ & $\begin{array}{l}-0.0236 \\
(0.034)\end{array}$ & $\begin{array}{l}-0.0159 \\
(0.059)\end{array}$ & $\begin{array}{l}-0-061 \\
(0.066)\end{array}$ & $\begin{array}{l}0.045 \\
(0.051)\end{array}$ \\
\hline Credit gr & $\begin{array}{l}-0.0001 * * * \\
(0.00003)\end{array}$ & $\begin{array}{l}-0.0001 * * * \\
(0.0003)\end{array}$ & $\begin{array}{l}0.0001 * * * \\
(0.00003)\end{array}$ & $\begin{array}{l}-0.0002 * * * \\
(0.00005)\end{array}$ & --- \\
\hline CAoGDP & $\begin{array}{l}0.076 * * * \\
(0.024)\end{array}$ & $\begin{array}{l}0.076 * * * \\
(0.027)\end{array}$ & $\begin{array}{l}0.076 * * \\
(0.027)\end{array}$ & $\begin{array}{l}0.085^{* *} \\
(0.042)\end{array}$ & --- \\
\hline BBoGDP & $\begin{array}{l}-0.102 * * \\
(0.042)\end{array}$ & $\begin{array}{l}-0.101^{* *} \\
(0.046)\end{array}$ & $\begin{array}{l}-0.101 * * \\
(0.04)\end{array}$ & $\begin{array}{l}-0.078 \\
(0.047)\end{array}$ & --- \\
\hline M2oRES & $\begin{array}{l}0.0001 \\
(0.001)\end{array}$ & $\begin{array}{l}0.0001 \\
(0.0001)\end{array}$ & $\begin{array}{l}0.0009 \\
(0.0007)\end{array}$ & $\begin{array}{l}0.0001 \\
(0.0001)\end{array}$ & --- \\
\hline Trade comp & $\begin{array}{l}0.021 * \\
(0.012)\end{array}$ & $\begin{array}{l}0.022^{*} \\
(0.012)\end{array}$ & $\begin{array}{l}0.021 * * \\
(0.011)\end{array}$ & $\begin{array}{l}0.014 \\
(0.016)\end{array}$ & $\begin{array}{l}0.023 * * \\
(0.010)\end{array}$ \\
\hline Africa & $\begin{array}{l}0.011^{* *} \\
(0.005)\end{array}$ & $\begin{array}{l}0.011^{*} \\
(0.005)\end{array}$ & $\begin{array}{l}0.010 * * \\
(0.004)\end{array}$ & $\begin{array}{l}0.005 \\
(0.007)\end{array}$ & $\begin{array}{l}0.021 * * * \\
(0.007)\end{array}$ \\
\hline ME & $\begin{array}{l}0.012 * * \\
(0.005)\end{array}$ & $\begin{array}{l}0.012 * * \\
(0.005)\end{array}$ & $\begin{array}{l}0.012 * * * \\
(0.004)\end{array}$ & $\begin{array}{l}0.009^{*} \\
(0.005)\end{array}$ & $\begin{array}{l}0.015^{* * * *} \\
(0.004)\end{array}$ \\
\hline WH & $\begin{array}{l}0.018 * * * \\
(0.004)\end{array}$ & $\begin{array}{l}0.018 * * * \\
(0.005)\end{array}$ & $\begin{array}{l}0.018 * * * \\
(0.0041)\end{array}$ & $\begin{array}{l}0.018 * * * \\
(0.006)\end{array}$ & $\begin{array}{l}0.023 * * * \\
(0.0042)\end{array}$ \\
\hline $\mathrm{EE}$ & $\begin{array}{l}0.024 * * * \\
(0.006)\end{array}$ & $\begin{array}{l}0.024 * * * \\
(0.007)\end{array}$ & $\begin{array}{l}0.024 * * * \\
(0.069)\end{array}$ & $\begin{array}{l}0.027 * * * \\
(0.009)\end{array}$ & $\begin{array}{l}0.024 * * * \\
(0.006)\end{array}$ \\
\hline Com banks & $\begin{array}{l}-0.0043^{*} \\
(0.0024)\end{array}$ & $\begin{array}{l}-0.004 * * \\
(0.002)\end{array}$ & $\begin{array}{l}-0.0055^{* *} \\
(0.0027)\end{array}$ & $\begin{array}{l}-0.005 \\
(0.0029)\end{array}$ & $\begin{array}{l}-0.0044 * \\
(0.0024)\end{array}$ \\
\hline Log assets & -- & -- & $\begin{array}{l}0.001 \\
(0.001)\end{array}$ & -- & -- \\
\hline Stock corr & --- & --- & --- & $\begin{array}{l}-0.002 \\
(0.008)\end{array}$ & --- \\
\hline PD & --- & --- & --- & --- & $\begin{array}{l}0.006 \\
(0.038)\end{array}$ \\
\hline $\mathrm{R}^{2}$ & 0.17 & 0.17 & 0.17 & 0.21 & 0.14 \\
\hline $\mathrm{N}$ & 367 & 367 & 367 & 268 & 340 \\
\hline
\end{tabular}

Notes. Dependent variable: bank flows between September 1997 and June 1998 normalised by each bank's total exposure to developing countries. $*, * *, * * *$ refer to $10 \%, 5 \%$ and $1 \%$ level of significance, respectively. Constant not reported. Standard errors in parentheses. OLS standard errors are corrected for heteroscedasticity using the Huber/White/sandwich estimator of variance. Reference region is Asia. Reference banking group is Land banks. For construction of variables see Table 6. Exchange rate appreciation is omitted owing to high correlation with credit growth. 
Table 8a. Results for Russian crisis

\begin{tabular}{|c|c|c|c|c|c|}
\hline & $\begin{array}{l}\text { (1) } \\
\text { Baseline } \\
\text { specification } \\
\text { All banks } \\
\text { OLS }\end{array}$ & $\begin{array}{l}(2) \\
\text { Baseline } \\
\text { specification } \\
\text { Land banks } \\
\text { OLS }\end{array}$ & $\begin{array}{l}\text { (3) } \\
\text { Baseline } \\
\text { specification } \\
\text { Commercial } \\
\text { banks } \\
\text { OLS }\end{array}$ & $\begin{array}{l}\text { (4) } \\
\text { Baseline } \\
\text { specification } \\
\text { All banks } \\
\text { OLS } \\
\text { Flows adjusted } \\
\text { for currency } \\
\text { fluctuations }\end{array}$ & $\begin{array}{l}\text { (5) } \\
\text { (1) with country } \\
\text { dummies } \\
\text { All banks } \\
\text { OLS }\end{array}$ \\
\hline Common L & $\begin{array}{l}0.004 \\
(0.015)\end{array}$ & $\begin{array}{l}-0.014 \\
(0.017)\end{array}$ & $\begin{array}{l}0.067 * * \\
(0.030)\end{array}$ & $\begin{array}{l}0.006285 \\
(0.0175)\end{array}$ & $\begin{array}{l}0.0004 \\
(0.014)\end{array}$ \\
\hline Wake up call & $\begin{array}{l}-0.182 * * * \\
(0.040)\end{array}$ & $\begin{array}{l}-0.164 * * * \\
(0.05)\end{array}$ & $\begin{array}{l}-0.204 * * * \\
(0.034)\end{array}$ & $\begin{array}{l}-0.1869385^{* * * *} \\
(0.041)\end{array}$ & $\begin{array}{l}-0.211 * * * \\
(0.057)\end{array}$ \\
\hline Credit gr & $\begin{array}{l}7 \mathrm{e}^{-07} \\
(0.00002)\end{array}$ & $\begin{array}{l}3.91 \mathrm{e}^{-06} \\
0.00003\end{array}$ & $\begin{array}{l}5.13 \mathrm{e}^{-06} \\
0.00002\end{array}$ & $\begin{array}{l}7.62 \mathrm{e}-06 \\
(0.00002)\end{array}$ & -- \\
\hline Exch App & $\begin{array}{l}-0.006 \\
(0.016)\end{array}$ & $\begin{array}{l}-0.005 \\
(0.017)\end{array}$ & $\begin{array}{l}-0.008 \\
(0.031)\end{array}$ & $\begin{array}{l}-0.0140 \\
(0.0189)\end{array}$ & --- \\
\hline CAoGDP & $\begin{array}{l}0.015 \\
(0.013)\end{array}$ & $\begin{array}{l}0.023 \\
(0.018)\end{array}$ & $\begin{array}{l}-0.003 \\
(0.020)\end{array}$ & $\begin{array}{l}0.0028 \\
(0.0178)\end{array}$ & --- \\
\hline BBoGDP & $\begin{array}{l}0.003 \\
(0.023)\end{array}$ & $\begin{array}{l}-0.005 \\
(0.027)\end{array}$ & $\begin{array}{l}0.019 \\
(0.037)\end{array}$ & $\begin{array}{l}0.0319 \\
(0.0281)\end{array}$ & --- \\
\hline M2oRES & $\begin{array}{l}0.000006 \\
(0.0001)\end{array}$ & $\begin{array}{l}-0.00001 \\
(0.0002)\end{array}$ & $\begin{array}{l}-0.00007 \\
(0.0002)\end{array}$ & $\begin{array}{l}0.0001 \\
(0.0001)\end{array}$ & --- \\
\hline Trade comp & $\begin{array}{l}0.0003 \\
(0.006)\end{array}$ & $\begin{array}{l}-0.003 \\
(0.009)\end{array}$ & $\begin{array}{l}0.0004 \\
(0.007)\end{array}$ & $\begin{array}{l}0.0048 \\
(0.006)\end{array}$ & --- \\
\hline Africa & $\begin{array}{l}-0.004 * * * \\
(0.001)\end{array}$ & $\begin{array}{l}-0.006 * * * \\
(0.002)\end{array}$ & $\begin{array}{l}-0.0004 \\
(0.0015)\end{array}$ & $\begin{array}{l}-0.0056 * * * \\
(0.0017)\end{array}$ & --- \\
\hline $\mathrm{ME}$ & $\begin{array}{l}-0.004 * * \\
(0.002)\end{array}$ & $\begin{array}{l}0.006^{* * *} \\
(0.002)\end{array}$ & $\begin{array}{l}0.0003 \\
(0.002)\end{array}$ & $\begin{array}{l}-0.0057 * * \\
(0.0022)\end{array}$ & --- \\
\hline WH & $\begin{array}{l}-0.002 \\
(0.0015)\end{array}$ & $\begin{array}{l}-0.003 \\
(0.002)\end{array}$ & $\begin{array}{l}-0.0003 \\
(0.002)\end{array}$ & $\begin{array}{l}-0.0033^{* *} \\
(0.0021)\end{array}$ & --- \\
\hline Asia & $\begin{array}{l}-0.005 * * \\
(0.002)\end{array}$ & $\begin{array}{l}-0.009 * * * \\
(0.003)\end{array}$ & $\begin{array}{l}0.004 \\
(0.004)\end{array}$ & $\begin{array}{l}-0.0067 * * * \\
(0.0026)\end{array}$ & --- \\
\hline Com banks & $\begin{array}{l}-0.0002 \\
(0.001) \\
\end{array}$ & --- & --- & $\begin{array}{l}0.00002 \\
(0.0011)\end{array}$ & $\begin{array}{l}0.0002 \\
(0.001)\end{array}$ \\
\hline $\mathrm{R}^{2}$ & 0.24 & 0.26 & 0.33 & 0.25 & 0.34 \\
\hline $\mathrm{N}$ & 415 & 272 & 143 & 374 & 415 \\
\hline
\end{tabular}

Notes. Dependent variable: bank flows between June 1998 and December 1998 normalised by each bank's total exposure to developing countries. *,**,*** refer to $10 \%, 5 \%$ and $1 \%$ level of significance,

respectively. Constant not reported. Standard errors in parentheses. OLS standard errors are corrected for heteroscedasticity using the Huber/White/sandwich estimator of variance. Reference region is Emerging Europe. Reference banking group is Land banks. Note that the sample size in (4) is smaller than in (1) because data on currency composition of claims was not available for five countries. Coefficients for the country dummy variables in (5) are not reported. For construction of variables see Table 6. 
Table 8b. Results for Russian crisis

\begin{tabular}{|c|c|c|c|c|c|}
\hline & $\begin{array}{l}\text { (6) } \\
\text { Baseline } \\
\text { specification } \\
\text { All banks } \\
\text { RE (banks) }\end{array}$ & $\begin{array}{l}\text { (7) } \\
\text { Baseline } \\
\text { specification } \\
\text { All banks } \\
\text { RE (country) }\end{array}$ & $\begin{array}{l}\text { (8) } \\
\text { (1) including } \\
\text { log assets } \\
\text { All banks } \\
\text { OLS }\end{array}$ & $\begin{array}{l}\text { (9) } \\
\text { (1) including } \\
\text { stock corr } \\
\text { All banks } \\
\text { OLS }\end{array}$ & $\begin{array}{l}\text { (10) } \\
\text { (1) including } \\
\text { PD } \\
\text { All banks } \\
\text { OLS }\end{array}$ \\
\hline Common L & $\begin{array}{l}0.004 \\
(0.026)\end{array}$ & $\begin{array}{l}0.003 \\
(0.012)\end{array}$ & $\begin{array}{l}0.004 \\
(0.015)\end{array}$ & $\begin{array}{l}0.010 \\
(0.019)\end{array}$ & $\begin{array}{l}0.005 \\
(0.016)\end{array}$ \\
\hline Wake up call & $\begin{array}{l}-0.184 * * * \\
(0.017)\end{array}$ & $\begin{array}{l}-0.187 * * * \\
(0.019)\end{array}$ & $\begin{array}{l}-0.182^{* * * *} \\
(0.040)\end{array}$ & $\begin{array}{l}-0.20 * * * \\
(0.045)\end{array}$ & $\begin{array}{l}-0.18 * * * \\
(0.039)\end{array}$ \\
\hline Credit gr & $\begin{array}{l}1.54 \mathrm{e}^{-06} \\
(0.00002)\end{array}$ & $\begin{array}{l}1.01 \mathrm{e}^{-06} \\
(0.00002)\end{array}$ & $\begin{array}{l}6.15 \mathrm{e}^{-07} \\
(0.00002)\end{array}$ & $\begin{array}{l}-0.00001 \\
(0.00004)\end{array}$ & --- \\
\hline Exch App & $\begin{array}{l}-0.005 \\
(0.012)\end{array}$ & $\begin{array}{l}-0.007 \\
(0.015)\end{array}$ & $\begin{array}{l}-0.006 \\
(0.016)\end{array}$ & $\begin{array}{l}-0.009 \\
(0.030)\end{array}$ & --- \\
\hline CAoGDP & $\begin{array}{l}0.015 \\
(0.018)\end{array}$ & $\begin{array}{l}0.016 \\
(0.022)\end{array}$ & $\begin{array}{l}0.015 \\
(0.014)\end{array}$ & $\begin{array}{l}-0.051 \\
(0.028)\end{array}$ & --- \\
\hline BBoGDP & $\begin{array}{l}0.002 \\
(0.020)\end{array}$ & $\begin{array}{l}0.001 \\
(0.024)\end{array}$ & $\begin{array}{l}0.003 \\
(0.022)\end{array}$ & $\begin{array}{l}0.023 \\
(0.033)\end{array}$ & --- \\
\hline Trade comp & $\begin{array}{l}-0.0005 \\
(0.007)\end{array}$ & $\begin{array}{l}0.0006 \\
(0.008)\end{array}$ & $\begin{array}{l}0.0003 \\
(0.006)\end{array}$ & $\begin{array}{l}-0.012 \\
(0.008)\end{array}$ & $\begin{array}{l}-0.002 \\
(0.006)\end{array}$ \\
\hline Africa & $\begin{array}{l}-0.0038 * \\
(0.0022)\end{array}$ & $\begin{array}{l}-0.004 \\
(0.003)\end{array}$ & $\begin{array}{l}-0.004 * * \\
(0.001)\end{array}$ & $\begin{array}{l}-0.014 * * \\
(0.005)\end{array}$ & $\begin{array}{l}-0.0032 * \\
(0.0018)\end{array}$ \\
\hline ME & $\begin{array}{l}-0.0037 \\
(0.0025)\end{array}$ & $\begin{array}{l}-0.004 \\
(0.003)\end{array}$ & $\begin{array}{l}-0.005 * * \\
(0.002)\end{array}$ & $\begin{array}{l}-0.013 * * * \\
(0.004)\end{array}$ & $\begin{array}{l}-0.003 \\
(0.001)\end{array}$ \\
\hline WH & $\begin{array}{l}-0.002 \\
(0.0017)\end{array}$ & $\begin{array}{l}-0.002 \\
(0.002)\end{array}$ & $\begin{array}{l}-0.002 \\
(0.002)\end{array}$ & $\begin{array}{l}-0.010 * * * \\
(0.003)\end{array}$ & $\begin{array}{l}-0.001 \\
(0.002)\end{array}$ \\
\hline Asia & $\begin{array}{l}-0.005^{* *} \\
(0.002)\end{array}$ & $\begin{array}{l}-0.004 * * \\
(0.002)\end{array}$ & $\begin{array}{l}-0.005^{* *} \\
(0.002)\end{array}$ & $\begin{array}{l}-0.013^{* * *} \\
(0.004)\end{array}$ & $\begin{array}{l}-0.005^{* *} \\
(0.002)\end{array}$ \\
\hline Com Banks & $\begin{array}{l}-0.0006 \\
(0.0027)\end{array}$ & $\begin{array}{l}-0.0001 \\
(0.001)\end{array}$ & $\begin{array}{l}0.0002 \\
(0.001)\end{array}$ & $\begin{array}{l}0.0005 \\
(0.0016)\end{array}$ & $\begin{array}{l}-0.0002 \\
(0.0011)\end{array}$ \\
\hline Log assets & --- & --- & $\begin{array}{l}-0.0002 \\
(0.0003)\end{array}$ & --- & --- \\
\hline Stock corr & --- & --- & -- & $\begin{array}{l}-0.0015 \\
(0.007)\end{array}$ & --- \\
\hline PD & --- & --- & --- & --- & $\begin{array}{l}0.016 \\
(0.012)\end{array}$ \\
\hline $\mathrm{R}^{2}$ & 0.24 & 0.24 & 0.24 & 0.24 & 0.24 \\
\hline $\mathrm{N}$ & 415 & 415 & 415 & 415 & 387 \\
\hline
\end{tabular}

Notes. Dependent variable: bank flows between June 1998 and December 1998 normalised by each bank's total exposure to developing countries. *,**, *** refer to $10 \%, 5 \%$ and $1 \%$ level of significance, respectively. Constant not reported. Standard errors in parentheses. OLS standard errors are corrected for heteroscedasticity using the Huber/White/sandwich estimator of variance. Reference region is Emerging Europe. Reference banking group is Land banks. For construction of variables see Table 6. 


\section{References}

BIS (1982), Management of Bank's International Lending (Country Risk Analysis and Country Exposure Measurement and Control). Basel Committee Publications No 1, Bank for International Settlements.

Bussiere, M and M Fratzscher (2002). 'Towards a new early warning system of financial crises', Working paper series 145, European Central Bank .

Caramazza, F, L Ricci and R Salgado (2000). 'Trade and financial Contagion in currency crises', IMF Working Paper 00/55.

Christiansen, H (2000), 'International Financial Contagion', Financial Market Trends No 76: $65-108$.

Claessens, S and K J Forbes (2001), 'International Financial Contagion', Kluwer Academic Press, Boston, MA.

Corsetti, G, P Pesenti and Nouriel Roubini (1998), 'What caused the Asian currency and financial crisis? Part A: A macroeconomic overview', NBER Working Paper Series, No 6833.

Corsetti, G and P Pesenti and N Roubini and C Tille (1998), 'Structural links and contagion effects in the Asian crisis: A welfare based approach', New York, NY: New York University.

Deutsche Bundesbank (1998): Monthly Report, August 1998.

Deutsche Bundesbank (1998): Instruction sheet for the reporting of large exposures and loans of 3 million deutsche Mark or more pursuant to sections 13 to 14 of the banking act, in: Banking Regulations 7.

Eichengreen, B, A K Rose and C Wyplosz (1996), 'Contagious currency crises', National Bureau of Economic Research Working Paper, Vol. No 5681.

Glick, R and A K Rose (1999), 'Contagion and trade: Why are currency crises regional?', Journal of International Money and Finance 18 (4): 603-617.

Goldberg, L S (2001), 'When is U.S. bank lending to emerging markets more volatile?', NBER Working Paper Series, No 8209.

IMF (1999), 'International Financial Contagion', in: World Economic Outlook, chapter 3: 66-87.

Fratzscher, M (2003), 'On currency crises and contagion', International Journal of Finance and Economics, 8, 2: 109 -129.

Goldstein, M (1998), 'The Asian Financial Crisis: Causes, Cures, and Systemic Implications', Policy Analyses in International Economics No 55, Institute for International Economics, Washington. 
Goldstein, M, G Kaminsky and C M Reinhart (2000), 'Assessing financial vulnerability', Institute for International Economics, Washington DC.

Hernandez, L F and R O Valdez (2001), 'What drives contagion: Trade, Neighborhood, or financial links?', IMF Working Paper 01/29.

Jeanneau, Serge, and Marian Micu (2002), 'Determinants of international bank lending to emerging market countries', BIS Working Papers, No 112, Bank for International Settlements.

Kaminski, G and C M Reinhard (2000), 'On crises, contagion, and confusion', Journal of International Economics 51: 145-168.

Kaminski, G and C M Reinhard (2001), 'Bank lending and contagion: Evidence from the Asian crisis', in: Regional and global capital flows: Macroeconomic causes and consequences, Chicago: University of Chicago Press for NBER.

Kaminski, G, C M Reinhard and C A Vegh (2003). 'The unholy trinity of financial contagion', NBER Working Papers 10061, NBER.

Kodres L E and M Pritsker (2002), 'A rational expectations model of financial contagion', Journal of Finance. April, LVII:2, pp 769-800.

Nestmann, T, M Wedow and N v. Westernhagen (2003). 'A micro data-set on foreign claims of German banks', Deutsche Bundesbank, mimeo.

Park, Y C, and C-Y Song (2001): 'Financial contagion in the East Asian crisis: With special reference to the Republic of Korea', in: International Financial Contagion, Stijn Claessens and Kristin J Forbes (eds), Kluwer Academic Press, Boston, MA: 241-265.

Rijckeghem v, C and B Weder (2001), 'Sources of contagion: Is it finance or trade?', Journal of International Economics 54: 293-308.

Rijckeghem v, C and B Weder (2003), 'Spillovers through banking centers: a panel analysis of bank flows', Journal of International Money and Finance 22: 483-509.

Schinasi, G and T Smith (2000), 'Portfolio diversification, leverage, and financial Contagion', IMF Staff Papers, 47: 159-176.

Sinn, H-W (1999), ‘The German State Banks’, Edward Elgar, Cheltenham, UK. 


\section{The following Discussion Papers have been published since 2003:}

\section{Series 1: Studies of the Economic Research Centre}

January 2003 Testing mean-variance efficiency in CAPM with possibly non-gaussian errors: an exact simulation-based approach

January 2003 Finite-sample distributions of self-normalized sums

January 2003 The stock return-inflation puzzle and the asymmetric causality in stock returns, inflation and real activity

February 2003 Multiple equilibrium overnight rates in a dynamic interbank market game

February 2003 A comparison of dynamic panel data estimators: Monte Carlo evidence and an application to the investment function

March 2003 A Vectorautoregressive Investment Model (VIM) And Monetary Policy Transmission: Panel Evidence From German Firms

March 2003 The international integration of money markets in the central and east European accession countries: deviations from covered interest parity, capital controls and inefficiencies in the financial sector

March 2003 The international integration of foreign exchange markets in the central and east European accession countries: speculative efficiency, transaction costs and exchange rate premiums
Marie-Claude Beaul Jean-Marie Dufour Lynda Khalaf

Jeong-Ryeol Kim

Jeong-Ryeol Kim

Jens Tapking

Andreas Behr

Joerg Breitung

Robert S. Chirinko

Ulf von Kalckreuth

Sabine Herrmann

Axel Jochem

Sabine Herrmann

Axel Jochem 
March 2003

Determinants of German FDI:

New Evidence from

Micro-Data

March 2003 On the Stability of

Different Financial Systems

April 2003 Determinants of German Foreign

Direct Investment in Latin American and

Asian Emerging Markets in the 1990s

June 2003 Active monetary policy, passive fiscal

policy and the value of public debt:

some further monetarist arithmetic

June 2003 Bidder Behavior in Repo Auctions

without Minimum Bid Rate:

Evidence from the Bundesbank

June 2003 Did the Bundesbank React to

Stock Price Movements?

$152003 \quad$ Money in a New-Keynesian model

estimated with German data

162003 Exact tests and confidence sets for the

tail coefficient of $\alpha$-stable distributions

$172003 \quad$ The Forecasting Performance of

German Stock Option Densities

182003 How wacky is the DAX? The changing

structure of German stock market volatility
Claudia Buch

Jörn Kleinert

Farid Toubal

Falko Fecht

Torsten Wezel

Leopold von Thadden

Tobias Linzert

Dieter Nautz

Jörg Breitung

Martin T. Bohl

Pierre L. Siklos

Thomas Werner

Jana Kremer

Giovanni Lombardo

Thomas Werner

Jean-Marie Dufour

Jeong-Ryeol Kurz-Kim

B R Craig, E Glatzer,

J Keller, M Scheicher

Jelena Stapf

Thomas Werner 
12004 Foreign Bank Entry into Emerging Economies:

An Empirical Assessment of the Determinants

and Risks Predicated on German FDI Data Torsten Wezel

22004 Does Co-Financing by Multilateral Development

Banks Increase "Risky" Direct Investment in

Emerging Markets? -

Evidence for German Banking FDI Torsten Wezel

32004 Policy Instrument Choice and Non-Coordinated Giovanni Lombardo Monetary Policy in Interdependent Economies Alan Sutherland

$42004 \quad$ Inflation Targeting Rules and Welfare in an Asymmetric Currency Area Giovanni Lombardo

52004 FDI versus cross-border financial services: Claudia M. Buch The globalisation of German banks Alexander Lipponer

$62004 \quad$ Clustering or competition? The foreign Claudia M. Buch investment behaviour of German banks Alexander Lipponer

72004 PPP: a Disaggregated View Christoph Fischer

82004 A rental-equivalence index for owner-occupied Claudia Kurz housing in West Germany 1985 to 1998 Johannes Hoffmann

92004 The Inventory Cycle of the German Economy Thomas A. Knetsch

102004 Evaluating the German Inventory Cycle Using Data from the Ifo Business Survey Thomas A. Knetsch

$112004 \quad$ Real-time data and business cycle analysis in Germany Jörg Döpke

122004 Business Cycle Transmission from the US to Germany - a Structural Factor Approach Sandra Eickmeier 
132004 Consumption Smoothing Across States and Time: George M.

International Insurance vs. Foreign Loans

von Furstenberg

142004 Real-Time Estimation of the Output Gap

in Japan and its Usefulness for

Inflation Forecasting and Policymaking Koichiro Kamada

$152004 \quad$ Welfare Implications of the Design of a

Currency Union in Case of Member Countries

of Different Sizes and Output Persistence Rainer Frey

162004 On the decision to go public: Ekkehart Boehmer

Evidence from privately-held firms Alexander Ljungqvist

$17 \quad 2004 \quad$ Who do you trust while bubbles grow and blow?

A comparative analysis of the explanatory power

of accounting and patent information for the

Fred Ramb

market values of German firms

Markus Reitzig

182004 The Economic Impact of Venture Capital

Astrid Romain, Bruno

van Pottelsberghe

192004 The Determinants of Venture Capital:

Astrid Romain, Bruno

Additional Evidence

van Pottelsberghe

$202004 \quad$ Financial constraints for investors and the

speed of adaption: Are innovators special? Ulf von Kalckreuth

$212004 \quad$ How effective are automatic stabilisers?

Theory and results for Germany and other Michael Scharnagl

OECD countries

Karl-Heinz Tödter

222004 Asset Prices in Taylor Rules: Specification,

Pierre L. Siklos

Estimation, and Policy Implications for the

Thomas Werner

ECB

Martin T. Bohl 
$23 \quad 2004 \quad$ Financial Liberalization and Business

Cycles: The Experience of Countries in Lúcio Vinhas

the Baltics and Central Eastern Europe de Souza

242004 Towards a Joint Characterization of

Monetary Policy and the Dynamics of

the Term Structure of Interest Rates Ralf Fendel

$252004 \quad$ How the Bundesbank really conducted

monetary policy: An analysis based on

real-time data

Christina Gerberding

Andreas Worms

Franz Seitz

262004 Real-time Data for Norway:

T. Bernhardsen, Ø. Eitrheim,

Challenges for Monetary Policy

A.S. Jore, Ø. Røisland

272004 Do Consumer Confidence Indexes Help

Forecast Consumer Spending in Real Time?

Dean Croushore

$28 \quad 2004 \quad$ The use of real time information in

Maritta Paloviita

Phillips curve relationships for the euro area

David Mayes 


\section{Series 2: Banking and Financial Supervision}

$12003 \quad$ Measuring the Discriminative Power

B. Engelmann,

of Rating Systems

E. Hayden, D. Tasche

$22003 \quad$ Credit Risk Factor Modeling and

A. Hamerle,

the Basel II IRB Approach

T. Liebig, D. Rösch

$12004 \quad$ Forecasting Credit Portfolio Risk

A. Hamerle,

T. Liebig, H. Scheule

22004 Systematic Risk in Recovery Rates -

An Empirical Analysis of US Corporate

Credit Exposures

Klaus Düllmann

Monika Trapp

32004 Does capital regulation matter for bank

Frank Heid

behaviour? Evidence for German savings

Daniel Porath

banks

Stéphanie Stolz

$42004 \quad$ German bank lending during

F. Heid, T. Nestmann, emerging market crises:

B. Weder di Mauro,

A bank level analysis

N. von Westernhagen 